\title{
Hindcast experiments of tropospheric composition during the summer 2010 fires over western Russia
}

\author{
V. Huijnen ${ }^{1}$, J. Flemming ${ }^{2}$, J. W. Kaiser ${ }^{2}$, A. Inness ${ }^{2}$, J. Leitão ${ }^{3}$, A. Heil ${ }^{4}$, H. J. Eskes ${ }^{1}$, M. G. Schultz ${ }^{4}$, A. Benedetti ${ }^{2}$, \\ J. Hadji-Lazaro ${ }^{5}$, G. Dufour ${ }^{6}$, and M. Eremenko ${ }^{6}$ \\ ${ }^{1}$ Royal Netherlands Meteorological Institute, De Bilt, The Netherlands \\ ${ }^{2}$ European Centre for Medium-Range Weather Forecasts (ECMWF), Reading, UK \\ ${ }^{3}$ Institute of Environmental Physics, University of Bremen, Bremen, Germany \\ ${ }^{4}$ Forschungszentrum Jülich, Germany \\ ${ }^{5}$ UPMC Univ. Paris 06; Université Versailles St.-Quentin; CNRS/INSU, LATMOS-IPSL, Paris, France \\ ${ }^{6}$ Laboratoire Inter-universitaire des Systèmes Atmosphériques (LISA), UMR7583, CNRS/INSU - Universités Paris Est \\ Créteil et Paris Diderot, Créteil, France
}

Correspondence to: V. Huijnen (huijnen@knmi.nl)

Received: 10 November 2011 - Published in Atmos. Chem. Phys. Discuss.: 5 December 2011

Revised: 5 April 2012 - Accepted: 1 May 2012 - Published: 15 May 2012

\begin{abstract}
The severe wildfires in western Russia during July-August 2010 coincided with a strong heat wave and led to large emissions of aerosols and trace gases such as carbon monoxide $(\mathrm{CO})$, hydrocarbons and nitrogen oxides into the troposphere. This extreme event is used to evaluate the ability of the global MACC (Monitoring Atmospheric Composition and Climate) atmospheric composition forecasting system to provide analyses of large-scale pollution episodes and to test the respective influence of a priori emission information and data assimilation on the results. Daily 4-day hindcasts were conducted using assimilated aerosol optical depth (AOD), $\mathrm{CO}$, nitrogen dioxide $\left(\mathrm{NO}_{2}\right)$ and ozone $\left(\mathrm{O}_{3}\right)$ data from a range of satellite instruments. Daily fire emissions were used from the Global Fire Assimilation System (GFAS) version 1.0, derived from satellite fire radiative power retrievals.

The impact of accurate wildfire emissions is dominant on the composition in the boundary layer, whereas the assimilation system influences concentrations throughout the troposphere, reflecting the vertical sensitivity of the satellite instruments. The application of the daily fire emissions reduces the area-average mean bias by $63 \%$ (for $\mathrm{CO}$ ), $60 \%$ $\left(\mathrm{O}_{3}\right)$ and $75 \%\left(\mathrm{NO}_{2}\right)$ during the first $24 \mathrm{~h}$ with respect to independent satellite observations, compared to a reference simulation with a multi-annual mean climatology of biomass burning emissions. When initial tracer concentrations are further constrained by data assimilation, biases are reduced by
\end{abstract}

87, 67 and $90 \%$. The forecast accuracy, quantified by the mean bias up to $96 \mathrm{~h}$ lead time, was best for all compounds when using both the GFAS emissions and assimilation. The model simulations suggest an indirect positive impact of $\mathrm{O}_{3}$ and $\mathrm{CO}$ assimilation on hindcasts of $\mathrm{NO}_{2}$ via changes in the oxidizing capacity.

However, the quality of local hindcasts was strongly dependent on the assumptions made for forecasted fire emissions. This was well visible from a relatively poor forecast accuracy quantified by the root mean square error, as well as the temporal correlation with respect to ground-based $\mathrm{CO}$ total column data and AOD. This calls for a more advanced method to forecast fire emissions than the currently adopted persistency approach.

The combined analysis of fire radiative power observations, multiple trace gas and aerosol satellite observations, as provided by the MACC system, results in a detailed quantitative description of the impact of major fires on atmospheric composition, and demonstrate the capabilities for the realtime analysis and forecasts of large-scale fire events.

\section{Introduction}

In summer 2010, western Russia experienced a long atmospheric blocking period (Matsueda, 2011, Dole et al., 2011) resulting in a strong heat wave, which started around 
27 June and lasted until 14 August. Within a region of $1000 \times 1000 \mathrm{~km}^{2}$ around Moscow, temperatures were approximately $5-10^{\circ} \mathrm{C}$ warmer and relative humidity was 20 $40 \%$ lower than normal (Dole et al., 2011; Witte et al., 2011). The combination of high temperatures and drought made the vegetation vulnerable to fires, including the peat soil deposits that are common in this region. The Moderate Resolution Imaging Spectroradiometer (MODIS) instrument observed increased intensities of fire radiative power (FRP) over western Russia from 20 July onwards, and these fires resulted in periods of high pollution levels in Moscow and its vicinity. The combination of hot temperatures and pollutants emitted from the fires was estimated to have led to a significant increase in deaths in Moscow (van Donkelaar et al., 2011).

A range of observations were used in various studies to characterize the tropospheric composition during this episode, including in-situ data for fine and coarse aerosol mass $\left(\mathrm{PM}_{2.5}\right.$ and $\mathrm{PM}_{10}$, van Donkelaar et al., 2011), aerosol optical thickness (Chubarova et al., 2012) ozone $\left(\mathrm{O}_{3}\right)$ and carbon monoxide (CO) (Konovalov et al., 2011; Elansky et al., 2011), CO total columns (Yurganov et al., 2011), as well as space-based information of CO total columns from Atmospheric Infrared Sounder (AIRS), and aerosol optical depth (AOD) and single-scattering albedo from Ozone Monitoring Instrument (OMI) (Witte et al., 2011; Mei et al., 2011).

In addition, it had been shown before that fire episodes can be analyzed by the Infrared Atmospheric Sounding Interferometer (IASI) CO (Turquety et al., 2009) as well as nitrogen dioxide $\left(\mathrm{NO}_{2}\right)$ and formaldehyde $(\mathrm{HCHO})$ observations from the OMI and Scanning Imaging Absorption SpectroMeter for Atmospheric ChartographY (SCIAMACHY) instruments (e.g., Mebust et al., 2011; Stavrakou et al., 2009). Model studies assessing estimates of emissions for $\mathrm{CO}$ (Konovalov et al., 2011, Yurganov et al., 2011, Fokeeva et al., 2011), and aerosol (van Donkelaar et al., 2011; Kaiser et al., 2012) have been reported for the 2010 Russian fires.

The pollution levels by aerosol, $\mathrm{CO}$ and $\mathrm{O}_{3}$ in Moscow varied greatly during the period, both due to changing wind directions, and due to variations in fire emissions. Meteorological conditions during a heat wave are well known to affect tropospheric composition (Ordóñez et al., 2010). Changes in land surface parameters can alter dry deposition over vegetation (Vautard et al., 2005), and biogenic emissions (Lee et al., 2006, Solberg et al., 2008). Apart from these direct effects, trace gas concentrations vary due to perturbations of the chemical production and loss rates (e.g., Duncan et al., 2003). Additionally, depending on the optical properties of emitted aerosol, $\mathrm{O}_{3}$ and $\mathrm{NO}_{2}$ photolysis rates can be reduced (Real et al., 2007).

All these factors demand a comprehensive modeling framework in order to produce a realistic analysis and forecast of all aspects influencing tropospheric composition. This includes the use of data assimilation of meteorology and chemical composition, as well as accurate time- and space resolved near real-time (NRT) emission estimates (Hodzic et al., 2007, Menut and Bessagnet, 2010).

Several systems exist that aim to combine various observational data sources to obtain a complete and consistent view of the atmospheric composition. In the United States, an assimilation system for atmospheric composition is developed at the National Aeronautics and Space Administration (NASA)/Global Modeling and Assimilation Office (GMAO; see http://gmao.gsfc.nasa.gov). Also the National Oceanic and Atmospheric Administration (NOAA)/National Weather Service (NWS) in collaboration with the US Environmental Protection Agency (EPA) developed a data assimilation system that is used for operational air quality forecasting. Other examples of chemical data assimilation strategies are described in Sandu and Chai (2011).

In this context the MACC (Monitoring Atmospheric Composition and Climate, http://www.gmes-atmosphere.eu) project is a European initiative to achieve a complete and consistent view of the atmospheric composition, and to establish connections between chemical composition and weather forecasts, which in future may improve weather forecasts (Zhang, 2008; Grell and Baklanov, 2011).

In MACC, analyses and forecasts of atmospheric composition are routinely produced based on the coupled system CTM-IFS (Chemistry Transport Model - Integrated Forecast System, Flemming et al., 2009), extended with an aerosol model within the IFS (Morcrette et al., 2009, Benedetti et al., 2009). This data assimilation system makes use of analyses of both meteorology and chemical composition (Hollingsworth et al., 2008). Thus, it is able to monitor variations in chemical composition due to varying meteorology, such as episodes of increased ozone levels caused by heat waves (Ordóñez et al., 2010), or the onset of the ozone hole (Flemming et al., 2011).

The impact of fire emissions on atmospheric composition is long recognized (e.g., Duncan et al., 2003). Various systems for the generation of up-to-date, or even NRT global fire emission estimates have been reported (van der Werf et al., 2010; Wiedinmyer et al., 2010). Chemical composition in fire plumes is assessed using a range of satellite instruments as well as model results from various systems, some of them including chemical data assimilation (Verma et al., 2009; Dupont et al., 2012; Val Martin et al., 2006; Real et al., 2007). Uncertainties in fire inventories on the modeling of atmospheric composition, e.g., Williams et al. (2012), and long-range transport (Miller et al., 2011; McMillan et al., 2010; Elguindi et al., 2010) have previously been quantified.

Within MACC, a NRT daily fire emission estimate based on FRP observations from MODIS was developed: the Global Fire Assimilation System (GFAS, Kaiser et al., 2012). In this study we assess the capability of the MACC system using NRT fire emission estimates to forecast chemical composition a few days in advance. These forecasts are relevant to serve as boundary conditions to regional air quality models, as distant emissions can potentially influence air quality 
Table 1. Summary of satellite data used in the assimilation. Blacklist criteria: variational quality control (QC), Solar Elevation (SOE) and latitude (LAT).

\begin{tabular}{|c|c|c|c|c|c|c|}
\hline Species & Instrument & Satellite & $\begin{array}{l}\text { Data } \\
\text { product }\end{array}$ & $\begin{array}{l}\text { Averaging } \\
\text { kernels used }\end{array}$ & $\begin{array}{l}\text { Blacklist } \\
\text { criteria }\end{array}$ & Reference \\
\hline $\mathrm{CO}$ & IASI & METOP-A & Total column & yes & $\mathrm{QC}>0$ & Hurtmans et al. (2012) \\
\hline $\mathrm{O}_{3}$ & SCIAMACHY & ENVISAT & Total colum & no & $\mathrm{QC}>0 \mathrm{SOE}<6^{\circ}$ & Eskes et al. (2005) \\
\hline $\mathrm{O}_{3}$ & SBUV/2 & NOAA-17, NOAA-18 & Partial column & no & $\mathrm{QC}>0 \mathrm{SOE}<6^{\circ}$ & Bhartia et al. (1996) \\
\hline $\mathrm{O}_{3}$ & MLS & AURA & Profiles & no & $\mathrm{QC}>0$ & Waters et al. (2006) \\
\hline $\mathrm{NO}_{2}$ & OMI & AURA & Tropospheric column & yes & $\mathrm{QC}>0$ LAT $<60^{\circ} \mathrm{S}$ LAT $>60^{\circ} \mathrm{N}$ & Boersma et al. (2007) \\
\hline
\end{tabular}

(Hodzic et al., 2007; Pfister et al., 2011). For instance, for the 2010 Russian fires smoke particles have been reported over Finland (Kaiser et al., 2012).

The summer 2010 wildfires over western Russia provide an opportunity for a comprehensive assessment of the MACC assimilation/forecast system for this type of extreme pollution event. In this paper, we focus on the following questions: What is the relative importance of (1) the chemical data assimilation and (2) the NRT fire emission estimates on the accuracy of forecasts of tropospheric composition? What are direct effects, and which effects can be attributed to chemical interaction within the system, e.g. by persistent changes in the oxidative capacity? These questions may help to identify causes of variations in forecast accuracy from the perspective of both the modeling and the observing framework and can provide guidelines to improve them. For this purpose several hindcast (i.e. retrospective forecast) experiments with different model settings have been evaluated against independent satellite and ground-based observations. We focus on an assessment of the model in the free troposphere, for which the MACC global system is mainly designed for.

The paper is structured as follows: We describe the assimilation and forecast framework, together with the GFAS system in Sect. 2. In Sect. 3 various hindcast experiments are evaluated against independent observations for the heat wave period in western Russia. The interactions of the different modeling components with each other are explicitly discussed in Sect. 4. We end this paper with a summary and conclusions from the analysis performed.

\section{The MACC system and experiment setup}

\subsection{The global assimilation and forecast system}

The MACC system (Hollingsworth et al., 2008) is used to perform assimilation and hindcast experiments of the chemical composition of the troposphere and stratosphere on a global scale. Daily analyses and forecasts of greenhouse gases, reactive gases and aerosols, as well as a comprehensive reanalysis of atmospheric composition data over the period 2003-2010 are available via the MACC project web- portal (http://www.gmes-atmosphere.eu/data/). Aerosols are modeled within the IFS (Morcrette et al. 2009). The chemistry of reactive gases is calculated by a separate chemistry transport model. For this study we use the TM5 model (Huijnen et al., 2010a), which is coupled to the IFS via the OASIS4 coupler (Redler et al., 2010), as described in Flemming et al. (2009). At the moment no interaction between aerosols and trace gas concentrations is considered.

The ECMWF 4D-Var meteorological assimilation system has been extended to assimilate chemically reactive trace gas concentrations and AOD from satellite retrievals (Inness et al., 2009; Benedetti et al., 2009). In the daily analyses for 2010, 7 retrieval products from 7 satellite instruments were routinely assimilated, see Table 1 . The observational data are thinned to $1^{\circ} \times 1^{\circ}$ resolution. Background error statistics for reactive gases have been derived using the NMC method (Parish and Derber, 1992), which currently does not account for high variability in emissions or the correlation between different trace gases. Variational quality control (Andersson and Järvinen, 1999) and first guess checks are switched off for $\mathrm{CO}$ and $\mathrm{NO}_{2}$, to avoid that observations with high values that are very different from the background values would be given only little weight in the analysis or even be rejected. As an example, the mean averaging kernel for the IASI CO product over western Russia, between 20 July and 15 August, is given in Fig. 1. It shows that the instrument is sensitive down to the surface (for daytime observations), but the largest sensitivity to $\mathrm{CO}$ is at an altitude of approx. $400 \mathrm{hPa}$. By constraining both the ozone total column, using SCIAMACHY, OMI and SBUV, and the partial ozone column in the stratosphere, using MLS data, tropospheric $\mathrm{O}_{3}$ is directly affected by the assimilation procedure (Flemming et al., 2011). The 4D-Var system runs on T159L60 resolution, and minimizes the difference between the observation and the background fields during a 12 hour assimilation window.

The hindcast experiments use meteorology initialized by the ECMWF operational analyses. For the analysis of chemical composition the assimilation window is $12 \mathrm{~h}$, starting at 21:00 and 09:00 UTC. Every day at 00:00 UTC a 4-day (96 h) hindcast is started with the same system. The hindcasts use either the optimized initial concentration fields based on the data assimilation system, or the first day hindcasts for 


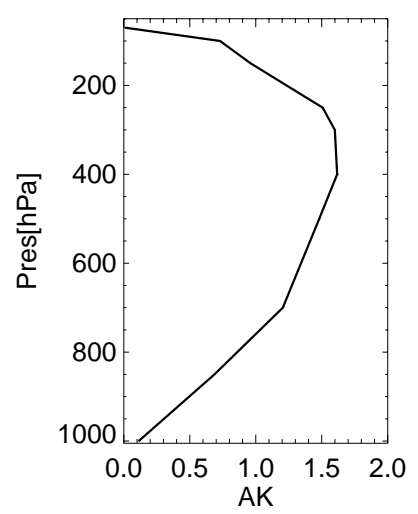

Fig. 1. Mean averaging kernel for IASI CO total columns over western Russia for 20 July-15 August 2010.

aerosol, $\mathrm{O}_{3}, \mathrm{CO}$ and $\mathrm{NO}_{\mathrm{x}}\left(=\mathrm{NO}+\mathrm{NO}_{2}\right)$ of the previous day for the reference hindcast runs. The four hindcast days are referred to as $\mathrm{D}+0$ to $\mathrm{D}+3$.

The TM5 model uses the tropospheric gas-phase chemistry version TM5-chem-v3.0 (Huijnen et al., 2010a), which is based on CBM-IV chemistry. It applies the same 60 level vertical discretization as the IFS, but the horizontal resolution is $3^{\circ}$ lon $\times 2^{\circ}$ lat, globally. The standard biomass burning emissions in the TM5 reference hindcast experiments are based on GFEDv2 (van der Werf et al., 2006) monthly mean 'climatological' emissions calculated from the years 20012006. The injection height of the reactive gases is assumed to extend up to $2 \mathrm{~km}$ (distributed as $20 \%$ in layers $0-100 \mathrm{~m}$, $100-500 \mathrm{~m}$ and $500-1000 \mathrm{~m}$, respectively, and $40 \%$ in 1000 $2000 \mathrm{~m}$ ), in line with the study from Val Martin et al. (2010).

\subsection{The GFAS emissions}

Numerous systems for the derivation of fire emission estimates have been developed. They are traditionally based on burned area, e.g. Andreae and Merlet (2001), van der Werf et al. (2006, 2010), Wiedinmyer et al. (2011). Several recent developments have instead used Fire Radiative Power (FRP) observations, e.g., Kaiser et al. (2009), Sofiev et al. (2009), Konovalov et al., (2011), because FRP has been shown to be directly proportional to the combustion and aerosol emission rates (Wooster et al., 2005; Ichoku and Kaufman, 2005; Heil et al., 2010). Common sources of uncertainty for all approaches are the land cover (and corresponding fire) type as well as the corresponding emission factors (Andreae and Merlet, 2001; Wiedinmyer et al., 2011; van der Werf et al., 2010; Mebust et al., 2011; Akagi et al., 2011). In the MACC project a NRT Global Fire Assimilation System (GFAS) was developed to estimate daily fire emission rates. The latest version (GFASv1.0), described in Kaiser et al. (2012), is based on FRP observations derived from the MODIS satellite instruments, and provides emission estimates on a daily basis with global coverage on a $0.5^{\circ} \times 0.5^{\circ}$ spatial grid.
Table 2. Definition of model configurations.

\begin{tabular}{lcl}
\hline Configuration & $\begin{array}{c}\text { Initial conditions } \\
\text { from assimilation }\end{array}$ & $\begin{array}{l}\text { Biomass burning } \\
\text { emissions }\end{array}$ \\
\hline CNT & No & GFEDv2-clim \\
GFAS & No & GFASv1.0 \\
Assim & Yes & GFEDv2-clim \\
Assim-GFAS & Yes & GFASv1.0 \\
\hline
\end{tabular}

The amount of trace gases released from the fires strongly depends on the predominant land cover type classification. The emission rate $f_{\mathrm{s}}$ for species $\mathrm{s}$ is calculated as:

$f_{\mathrm{s}}=\rho \alpha \beta_{\mathrm{s}}$.

where $\alpha$ denotes a biome-dependent factor for the conversion of FRP observations $\rho$ to the rate of dry matter burned and $\beta_{\mathrm{s}}$ are the biome-dependent emission factors from Andreae and Merlet (2001) with updates, which are of similar magnitude as those specified for GFEDv3.1 (van der Werf et al., 2010). In GFASv1.0 the conversion factor $\alpha$ was derived with a linear regression between the observed fire radiative energy and the dry matter burned in the GFEDv3.1 inventory. Specific conversion factors have been derived for eight dominant fire type classes (Heil et al., 2010; Kaiser et al., 2012). We note that an earlier attempt to generate emissions during the 2010 Russian fires episode yielded far lower CO emissions, partly because the biome distribution originally did not contain peat soils in the area around Moscow. The dominant fire type map was derived from the historic distribution of fire types in GFEDv3.1. For Russia, peat (histosols) and peaty soil areas were added in GFASv1.0, using information from Stolbovoi and Savin (2002) and (FAO 2003). GFASv1.0 is consistent with GFED3.1 within its accuracy limits and captures many small fires that are missing in the GFEDv3.1 inventory. Specifically, on a global, multi-annual average, the CO emissions of GFASv1.0 are $6 \%$ larger than GFEDv3.1, on a continental scale differences are typically $20 \%$. For aerosol emissions a global enhancement factor of 3.4 is introduced to compensate the under-estimation of bottom-up compared to top-down fire emissions at a regional to global scale (Kaiser et al., 2012). With this correction factor, the GFASv1.0 aerosol emissions of the western Russian fires of 2010 are consistent with eastern European AERONET observations (Kaiser et al., 2012).

The GFASv1.0 emissions for aerosols and all relevant reactive trace gases, including the non-methane volatile organic carbons (NMVOC's), are applied to the MACC system globally. A constant emission rate during the day is applied, which is a reasonable assumption for this case study where nighttime fire activity almost equaled daytime burning (Kaiser et al., 2012). The D+0 fire emissions are assumed to be constant during the full hindcast period. 
Table 3. Emission totals over western Russia for daily GFASv1.0, GFEDv3.1 monthly emissions, the GFEDv2 climatological emissions, as well as anthropogenic and biogenic emissions as used in the hindcast runs. Anthropogenic emissions are from RETRO (Schultz et al., 2007) and biogenic emissions from GEIA (Guenter et al., 2005) for CO and from ORCHIDEE (Latière et al., 2006) for NOx and HCHO.

\begin{tabular}{llcccc}
\hline & period & $1-15 / 7$ & $16-31 / 7$ & $1-15 / 8$ & $16-31 / 8$ \\
\hline $\mathrm{BC}(\mathrm{Gg} \mathrm{C})$ & GFASv1.0 & 2.4 & 5.4 & 7.9 & 1.6 \\
& GFEDv3.1 & 3.8 & 4.0 & 6.4 & 6.8 \\
& GFEDv2 clim & 3.2 & 3.5 & 4.1 & 4.4 \\
& Anthropogenic & 2.4 & 2.6 & 2.7 & 2.9 \\
\hline $\mathrm{CO}(\mathrm{Tg} \mathrm{CO})$ & GFASv1.0 & 0.45 & 5.2 & 7.0 & 0.67 \\
& GFEDv3.1 & 0.65 & 0.69 & 1.1 & 1.2 \\
& GFEDv2 clim & 0.50 & 0.53 & 0.60 & 0.64 \\
& Anthropogenic & 0.29 & 0.31 & 0.33 & 0.36 \\
& Biogenic & 0.43 & 0.46 & 0.38 & 0.40 \\
\hline \multirow{2}{*}{$\mathrm{NO}$ x (Gg NO) } & GFASv1.0 & 8 & 29 & 42 & 6 \\
& GFEDv3.1 & 19 & 20 & 35 & 38 \\
& GFEDv2 clim & 17 & 18 & 21 & 22 \\
& Anthropogenic & 47 & 50 & 52 & 55 \\
& Soil & 22 & 24 & 22 & 23 \\
\hline \multirow{2}{*}{$\mathrm{HCHO}(\mathrm{Gg} \mathrm{HCHO})$} & GFASv1.0 & 5.3 & 43.7 & 60.6 & 7.3 \\
& GFEDv3.1 & 9.9 & 10.6 & 18.8 & 20.1 \\
& GFEDv2 clim & - & - & - & - \\
& Anthropogenic & 11 & 12 & 11 & 12 \\
\hline
\end{tabular}

\subsection{Set-up of the model experiments}

To investigate the impact of both the assimilation system and the fire emissions, we performed four different 4-day hindcast runs, namely with and without initializing aerosol, $\mathrm{CO}$, $\mathrm{O}_{3}$ and $\mathrm{NO}_{\mathrm{x}}$ from assimilated fields, and using either the GFASv1.0 fire product or the GFEDv2 climatological emissions, see Table 2. All runs lasted up to 31 August, while the free runs started on 1 July, and the runs including assimilation on 15 July. In this study we will primarily focus on the evaluation of trace gas concentrations in the free troposphere, on a sub-continental scale $(\sim 1000 \times 1000 \mathrm{~km})$, having in mind the relatively coarse resolution of our chemistry model.

\section{Results}

\subsection{Meteorology and fire emissions}

Figure 2 illustrates the meteorological situation for the JulyAugust time period over western Russia, here defined as the region $35^{\circ} \mathrm{E}-70^{\circ} \mathrm{E}, 45^{\circ} \mathrm{N}-65^{\circ} \mathrm{N}$ (see also Fig. 3). The heat wave started around 27 June and lasted until $14 \mathrm{Au}$ gust. Temperatures reached maximum values of $39^{\circ} \mathrm{C}$, at the end of July, at individual locations (Matsueda, 2011), and were on average $5-10^{\circ} \mathrm{C}$ higher than normal (Dole et al., 2011). No significant precipitation was recorded during this period, which resulted in relative humidity levels $20-40 \%$ lower than normal (Witte et al., 2011). According to the me- teorological analyses, from mid-July onwards the soil wetness was below the critical level of $23 \%$, i.e. half the volumetric soil moisture at saturation, where water stress in vegetation is assumed to take place. From this period onwards the FRP of GFASv1.0 starts to increase, with extreme magnitudes on 29-30 July. On the evening of 10 August thunderstorms cleared the air over Moscow. After this date the recorded number of fires, and hence the fire emissions, were reduced. On 13 August the heat wave ended with heavy rain in Moscow and nearby areas.

Time series of the modeled $\mathrm{CO}$ emissions for the four dominating soil types over western Russia are also given in Fig. 2. They illustrate that the largest contribution to total CO emissions can be attributed to fires over agricultural land, which indeed covers the largest area within this region. However, on 29 and 30 July, approximately half of the total emissions were originating from peat fires. A snapshot of the CO emission map for 29 July (Fig. 3) shows that the region with large emissions is very localized at about $150 \mathrm{~km}$ east of Moscow and partly includes a region where fires were burning in dense peat deposits (Kaiser et al., 2012). Note that emission totals for 30 July were very similar to 29 July, because the quality control has removed the FRP observations for that day (Kaiser et al., 2012).

The total black carbon (BC), $\mathrm{CO}, \mathrm{NO}_{\mathrm{x}}$ and $\mathrm{HCHO}$ emissions from GFASv1.0 over western Russia, during 4 periods in July-August 2010, are given in Table 3. As a reference for GFASv1.0, the GFEDv3.1 emissions for the corresponding time period in 2010 are given. Also the GFEDv2 


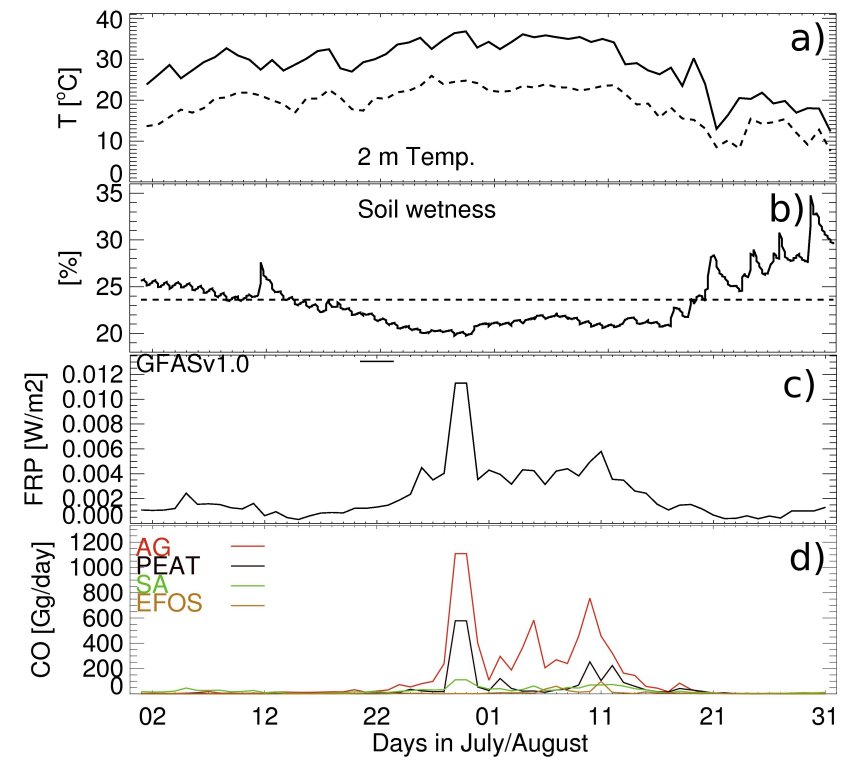

Fig. 2. Time series of (a) 2 meter daily maximum (solid) and minimum (dashed) temperature, and (b) soil wetness at a location east of Moscow $\left(42^{\circ} \mathrm{E}, 55^{\circ} \mathrm{N}\right)$ from ERA-Interim meteorology. The dashed line indicates the critical soil wetness level below which water stress is assumed to take place. Also shown are the c) GFASv1.0 FRP product averaged over western Russia, and (d) GFASv1.0 CO emissions over western Russia aggregated per fuel type. Only emissions from the four dominant fuel types are shown: AG: Agriculture, PEAT: Peat soils (histosols), SA: Savanna, EFOS: Extratropical forest (with partial burning of organic soil matter).

climatological (2001-2006) emissions, which are used in the reference hindcast experiments, are listed. The total GFASv1.0 emissions of CO between 16 July and 15 August are estimated as $12.2 \mathrm{Tg}$, of which $\sim 20 \%$ is attributed to peat burning. The $\mathrm{CO}$ emission totals are about 11 times larger than the GFEDv2 climatological emissions. Furthermore, the $\mathrm{CO}$ and $\mathrm{HCHO}$ emissions are much higher than the monthlymean GFEDv3.1 emissions. This is because GFEDv3.1 represents organic soil content in parts of Russia but only for the calculation of the dry matter combustion rate; the emission factors for peat are not applied outside tropical peat regions (van der Werf et al., 2010). GFASv1.0 applies emission factors for peat across all tropical and Russian peat land cover types. The finding of larger $\mathrm{CO}$ and $\mathrm{HCHO}$ emissions and lower $\mathrm{NO}_{\mathrm{x}}$ and $\mathrm{BC}$ emissions in GFAS than in GFEDv3.1 is consistent with the differences in respective emission factors for peat and agricultural fires. Finally, we note that the GFEDv3.1 average emissions over 2001-2006 for this region are considerably lower than those based on GFEDv2, as explained by van der Werf et al. (2010). For instance, $\mathrm{CO}$ emissions in GFEDv3.1 are lower by $\sim 40 \%$ than GFEDv2.

The corresponding anthropogenic and biogenic emissions used in the hindcast runs are also given. They illustrate that,

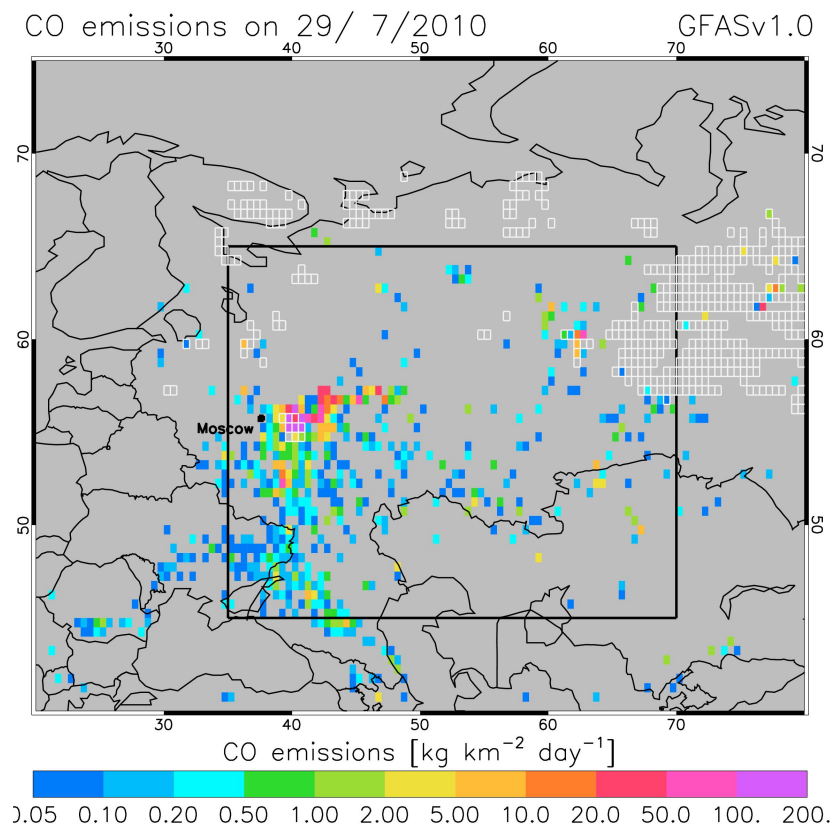

Fig. 3. Snapshot of CO emissions from GFASv1.0 on 29 July 2010. The white boxes indicate areas with peat soil as the dominant land cover type. Also indicated is the western Russia region $\left(35^{\circ} \mathrm{E}-\right.$ $\left.70^{\circ} \mathrm{E} \times 45^{\circ} \mathrm{N}-65^{\circ} \mathrm{N}\right)$.

specifically for $\mathrm{CO}$ and $\mathrm{HCHO}$, the GFASv1.0 biomass burning emissions contribute $90 \%$ and $82 \%$ of the total emissions, respectively, during the fire period. The $\mathrm{CO}$ emissions are $\sim 25 \%$ higher than Konovalov et al. (2011), who based their estimate on an optimization of FRP emission estimations using assimilated surface $\mathrm{CO}$ concentrations. Their estimated contribution from peat fires was $\sim 30 \%$.

During 29 and 30 July, the release of CO in GFASv1.0 is estimated as $\sim 3.6 \mathrm{Tg}$, contributing more than $30 \%$ of the total wildfire emissions over western Russia during July and August 2010. Fire emissions for $\mathrm{NO}_{\mathrm{x}}$ have almost doubled compared to the climatology and contribute $32 \%$ to the total emissions during this period.

\subsection{Evaluation of tropospheric composition}

The hindcast experiments (see Table 2) have been compared against various observations that were not used in the assimilation, as will be described in the corresponding subsections. For modeled AOD, ground-based observations done at the Moscow AERONET station $\left(37.5^{\circ} \mathrm{E}, 55.7^{\circ} \mathrm{N}\right)$ are used. In the case of $\mathrm{CO}, \mathrm{O}_{3}, \mathrm{NO}_{2}$ and $\mathrm{HCHO}$, retrievals from MOPITT, IASI and SCIAMACHY are used. CO total columns are further compared to ground-based observations at Moscow and Zvenigorod.

Forecast accuracy is quantified in terms of mean bias and Root Mean Square Error (RMSE), which have been calculated on a daily basis for each hindcast day and model grid-box. These were then averaged over the western Russia 

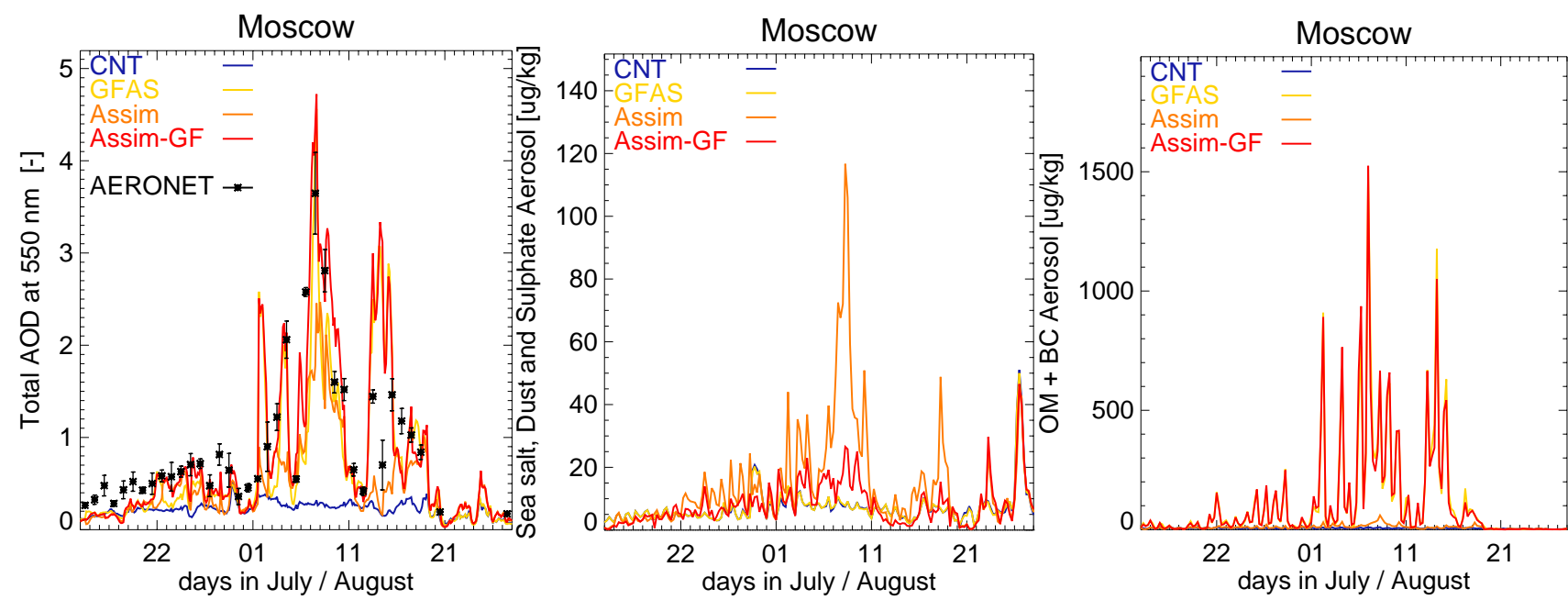

Fig. 4. Left) modeled total aerosol optical depth at D+0, compared to daily average AERONET observations at the Moscow station (black). The error bars reflect the daily variance in the available observations. Middle) total of seasalt, dust and sulphate aerosol, Right) total of organic matter and black carbon aerosol.

Table 4. Mean bias and RMSE of modeled AOD compared to the measurements from AERONET station at Moscow, between 20 July and 15 August, as function of the hindcast day.

\begin{tabular}{lrrrrrrrr}
\hline Model & \multicolumn{4}{c}{ Mean bias } & \multicolumn{5}{c}{ RMSE } \\
\hline & D+0 & D+1 & D+2 & D+3 & D+0 & D+1 & D+2 & D+3 \\
CNT & -0.83 & -0.79 & -0.78 & -0.73 & 0.85 & 0.81 & 0.79 & 0.75 \\
GFAS & -0.10 & -0.28 & -0.14 & 0.12 & 0.56 & 0.45 & 0.64 & 0.74 \\
Assim & -0.41 & -0.51 & -0.51 & -0.48 & 0.45 & 0.54 & 0.55 & 0.52 \\
Assim-GFAS & 0.08 & -0.05 & 0.02 & 0.27 & 0.43 & 0.41 & 0.54 & 0.77 \\
\hline
\end{tabular}

region and for the time frame of 20 July-15 August. For the AOD hindcasts, error measures are computed based on bias and RMSE with respect to the Moscow station only. Model AOD is interpolated to the time of the individual observations, and equal weight is given to all separate days in the time series. A similar procedure was followed for the evaluation of ground-based $\mathrm{CO}$ total columns.

\subsubsection{Aerosol optical depth and aerosol composition}

In Fig. 4, the modeled total AOD at 550nm from the four configurations is compared to AERONET observations at the Moscow station. Prior to the fire event (15-25 July) all model configurations tend to underestimate the AOD, although the configurations including initialization from assimilated AOD provide the best results. During the fire period, the run Assim captures a substantial part of the individual events, but frequently underestimates the magnitudes of the AODs. The run GFAS performs better, capturing most of the individual events. For instance, on 7 August, the very high levels of modeled AOD are in agreement with the observed daily mean AOD, with a value of 3.3 in GFAS compared to 3.6 in the observations.
Despite the similarity in AOD in the assimilation runs with/without GFASv1.0, the aerosol composition in these runs is very different, see Fig. 4. In the assimilation runs excluding GFASv1.0 emissions the increase in AOD is largely attributed to sulphate, dust and sea salt aerosols. In the other runs the organic matter and black carbon aerosols, which are the dominant aerosol types in smoke, are most enhanced. Therefore, realistic fire smoke emissions are essential for the ability to identify elevated aerosol levels as smoke. This behavior is expected as the aerosol assimilation scheme does not contain information of the aerosol composition but it relies on a realistic first guess estimation of emission (Benedetti et al., 2009).

The mean bias for run GFAS on D+0 is improved by $88 \%$ compared to run CNT and by $75 \%$ compared to run Assim, see Table 4. It remains better than for runs CNT and Assim throughout the hindcast period. This shows that the GFAS aerosol emissions also yield information on the total aerosol load that is more accurate than a climatology and even the MODIS AOD observations in this particular case. However, the information of GFAS and MODIS AOD is complementary and the mean bias of run Assim-GFAS is consequently the lowest of all runs up to D+2. The two runs with GFAS 

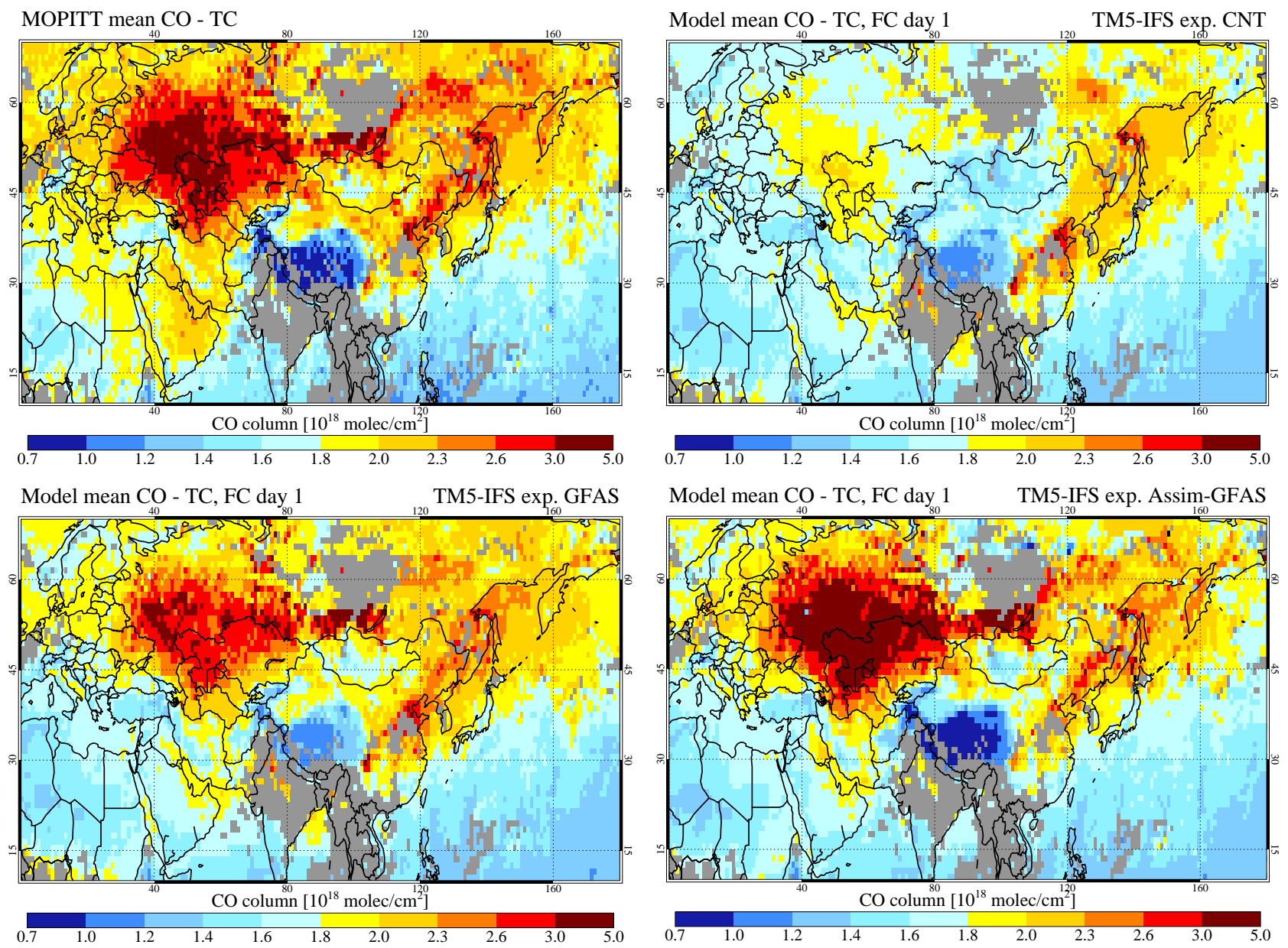

Fig. 5. Maps of mean CO columns from MOPITT-V4 for the time period 20 July-15 August 2010 compared to the kernel-weighted D+0 CO columns from the runs CNT, GFAS and Assim-GFAS.

Table 5. Temporal correlation of modeled AOD compared to the measurements from AERONET station at Moscow, between 20 July and 15 August ( $n=27$ ), as function of the hindcast day.

\begin{tabular}{lllll}
\hline Model & \multicolumn{5}{c}{$r^{2}$} \\
\hline & D+0 & D+1 & D+2 & D+3 \\
CNT & 0.09 & 0.09 & 0.15 & 0.04 \\
GFAS & 0.32 & 0.57 & 0.28 & 0.26 \\
Assim & 0.72 & 0.77 & 0.74 & 0.78 \\
Assim-GFAS & 0.50 & 0.68 & 0.48 & 0.26 \\
\hline
\end{tabular}

emissions show an increase in mean bias for $\mathrm{D}+3$. We interpret this as a symptom of a false alarm due to the assumption of persistence of the emissions from $\mathrm{D}+0$, in particular persistence of the extreme emission rates on 29-30 July. This false alarm is visible around 3 August in the AOD time series for D+3 in the top right panel of Fig. 12 in Kaiser et al. (2012).
The RMSE for run GFAS shows the positive impact of the GFAS emissions up to D+3 compared to run CNT. Run Assim-GFAS is better than the runs GFAS and Assim up to $\mathrm{D}+2$, once again showing the complementary positive impacts of the assimilation and the emissions. The RMSE for $\mathrm{D}+3$ in run Assim-GFAS is worse than the one in run Assim. This is a consequence of the strong sensitivity of this error metric to the actual variability in the emissions, which was very large between 28 July and 14 August. The RMSE is negatively affected by the emission persistency assumption made within each hindcast. A detailed interpretation is, however, beyond the scope of the present study because RMSE also becomes sensitive to the activity of the forecast at longer lead times.

The correlation of the modeled AOD with respect to the AERONET observations is given in Table 5. Best performance is obtained with run Assim $\left(r^{2}=0.72, n=27\right)$ for hindcast $\mathrm{D}+0$ and remains fairly constant at this level up to $\mathrm{D}+3$. For runs GFAS $\left(r^{2}=0.32\right.$ at $\left.\mathrm{D}+0\right)$ and Assim-GFAS $\left(r^{2}=0.50\right.$ at $\left.\mathrm{D}+0\right)$ the correlation degrades to $r^{2}=0.26$ at 


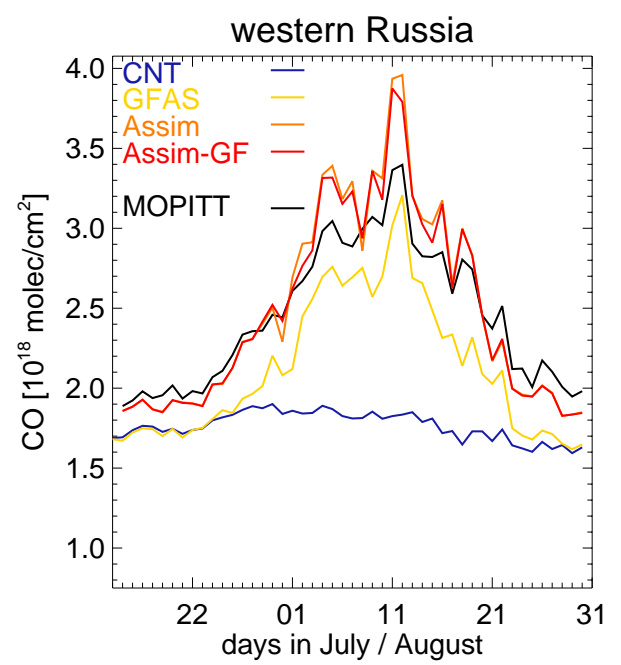

Fig. 6. Evolution of average kernel-weighted total columns over western Russia compared to MOPITT, for D+0 hindcasts.

$\mathrm{D}+3$, as a consequence of the high variability in the daily emissions.

In summary, the composition of the smoke aerosol plume is only realistic when GFAS emissions are used, the mean bias of AOD are improved by using the GFAS emissions throughout the AOD forecasts and the RMSE up to D+2. The RMSE and $r^{2}$ illustrate that the day-to-day variability in the emissions, and also AOD at the individual sites, are very high.

\subsubsection{Carbon monoxide}

For the evaluation of $\mathrm{CO}$, daytime total column observations from the MOPITT-V4 product (Deeter et al., 2010) have been used. Biases in the retrievals are on average below $5 \%$. We apply the MOPITT averaging kernels to the logarithm of the modeled profile. The average total CO columns over western Russia for run GFAS during the time of the fires show a strong improvement compared to the control run (Fig. 5). A similar pattern as that from MOPITT can be observed, although with an overall negative bias. A better agreement is found with run Assim-GFAS, which, on average, captured the observed magnitude well. The impacted region spans an area from the western border of Russia, $35^{\circ} \mathrm{E}$, up to $80^{\circ} \mathrm{E}$ and from $40^{\circ} \mathrm{N}$ to $65^{\circ} \mathrm{N}$, as a consequence of the relatively long $\mathrm{CO}$ lifetime.

The evolution of the area-average total columns over western Russia is presented in Fig. 6. Run GFAS accurately follows the observed area-average increase and decrease, but with a fairly constant negative offset during the whole simulation period. This suggests that the bias is not directly related to the GFAS CO emissions but rather to a general bias in $\mathrm{CO}$ over the northern hemisphere, see also Huijnen et al. (2010a).
When using assimilated IASI CO observations for the hindcast initialization, the average model total columns are low by $\sim 10^{17}$ molec $\mathrm{cm}^{-2}(\sim 6 \%)$ compared to MOPITTV4 during the initial phase, i.e., before 3 August. This bias is of the same magnitude as for the average over the extratropical Northern Hemisphere $\left(30^{\circ} \mathrm{N}-90^{\circ} \mathrm{N}\right)$. However, during the period of the highest CO columns (4-14 August), a positive bias of up to $0.5 \times 10^{18}$ molec $\mathrm{cm}^{-2}$ was found. These differences could be related to differences between IASI and MOPITT CO retrieval algorithms during this particular case, as discussed in Turquety et al. (2009) and George et al. (2009).

The assimilation runs with and without GFAS emissions do not show a significant difference for D+0 hindcasts, illustrating the dominating impact of the initialization by assimilation of IASI observations.

A quantitative analysis of the forecast error as function of the hindcast day is given in Table 6 . For the D+0 hindcasts the mean bias in run GFAS is $-0.29 \times 10^{18} \mathrm{molec} \mathrm{cm}^{-2}$. This remains fairly constant for the next three hindcast days and is less than half the bias obtained for run CNT.

It is interesting to consider the differences in the evolution of bias and RMSE at increasing forecast lengths between runs Assim and Assim-GFAS. Initially, for D+0, these numbers are similar, but while in run Assim a negative bias develops quickly, this happens to a lesser extent in run AssimGFAS, with an improvement of the mean bias relative to run Assim of $84 \%$ at $\mathrm{D}+3$. This demonstrates that the total amount of $\mathrm{CO}$ emissions, which is for this event much lower in run Assim (climatological) than in Assim-GFAS (persistency of D+0 emissions), is important to obtain a good forecast accuracy.

On the other hand, the values for RMSE increase considerably when including the GFAS emissions. This reflects the poor forecast accuracy of the precise emission pattern based on the persistency assumption in the fire emissions, as found before in the AOD analysis.

Additional to the space-based observations, we evaluate the model runs against ground-based CO total column observations based on spectrometers at the Moscow and Zvenigorod stations, as reported in Yurganov et al. (2011), Fig. 7. The Zvenigorod observation station is located $53 \mathrm{~km}$ west of the Moscow station. For this evaluation the modeled daytime $\mathrm{CO}$ profile has been spatially interpolated to the station location and convoluted with the averaging kernel corresponding to the observations. The magnitude of the total column observations from the two stations at the same day are always less than $10^{18}$ molec $\mathrm{cm}^{-2}$, except for 6 and 9 August, when the observations at Moscow are about two times larger than the ones at Zvenigorod. The model columns interpolated at the two stations are always very similar. This illustrates that very local events, causing differences in observations cannot be resolved at the current model resolution.

Different to the evaluation against space-based columns, a distinct difference between the runs with/without 
Table 6. Mean bias and RMSE of modeled total CO columns (units $10^{18}$ molec $\mathrm{cm}^{-2}$ ) compared to MOPITT V4 observations over western Russia between 20 July and 15 August, as function of the hindcast day.

\begin{tabular}{lrrrrrrrr}
\hline Model & \multicolumn{4}{c}{ Bias } & \multicolumn{4}{c}{ RMSE } \\
\hline & $\mathrm{D}+0$ & $\mathrm{D}+1$ & $\mathrm{D}+2$ & $\mathrm{D}+3$ & $\mathrm{D}+0$ & $\mathrm{D}+1$ & $\mathrm{D}+2$ & $\mathrm{D}+3$ \\
CNT & -0.79 & -0.78 & -0.78 & -0.77 & 0.91 & 0.91 & 0.90 & 0.90 \\
GFAS & -0.29 & -0.27 & -0.26 & -0.22 & 0.52 & 0.53 & 0.57 & 0.64 \\
Assim & 0.13 & -0.04 & -0.20 & -0.31 & 0.38 & 0.39 & 0.43 & 0.51 \\
Assim-GFAS & 0.10 & 0.04 & -0.02 & -0.05 & 0.40 & 0.46 & 0.54 & 0.62 \\
\hline
\end{tabular}

Table 7. Mean bias and RMSE of modeled total CO columns (units $10^{18}$ molec $\mathrm{cm}^{-2}$ ) compared to ground-based CO total column observations at the Moscow and Zvenigorod stations between 20 July and 15 August, as function of the hindcast day.

\begin{tabular}{lrrrrllll}
\hline Model & \multicolumn{4}{c}{ Bias } & \multicolumn{4}{c}{ RMSE } \\
\hline & D+0 & D+1 & D+2 & D+3 & D+0 & D+1 & D+2 & D+3 \\
CNT & -2.0 & -2.0 & -2.0 & -2.0 & 2.9 & 2.9 & 2.9 & 2.9 \\
GFAS & -0.2 & -0.7 & -0.8 & -0.7 & 2.0 & 1.9 & 1.7 & 1.9 \\
Assim & -1.2 & -1.4 & -1.5 & -1.5 & 2.1 & 2.3 & 2.3 & 2.4 \\
Assim-GFAS & 0.0 & -0.2 & -0.5 & -0.3 & 1.9 & 1.6 & 1.5 & 1.8 \\
\hline
\end{tabular}

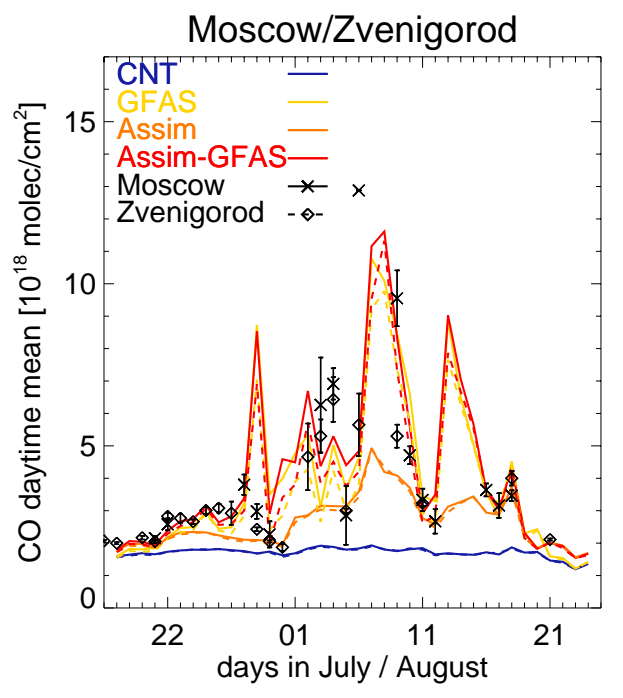

Fig. 7. Modeled daytime mean total CO column at D+0, compared to daily average ground-based column observations at the Moscow and Zvenigorod stations. The error bars reflect the daily variance in the available observations. Solid lines are model results interpolated to the Moscow station $\left(55.7^{\circ}\right.$ N. $\left.37.6^{\circ} \mathrm{E}\right)$. dashed lines correspond to Zvenigorod $\left(55.7^{\circ} \mathrm{N}, 36.8^{\circ} \mathrm{E}\right)$.

assimilation is clear, while both runs that apply GFAS emissions are now relatively similar. The rather modest increase in run Assim compared to CNT can be explained by the low sensitivity of IASI near the surface, as illustrated by the averaging kernel in Fig. 1, and because the a-priori profiles do not contain the high surface concentrations for this particular event.
The model versions with GFAS emissions capture the increase in $\mathrm{CO}$ columns during the first 10 days of August, but over-estimate concentrations on 29 July, related to the estimated high peat fire emissions close to Moscow on that day (Fig. 3). This is in contrast to AOD model results in Moscow for this day (see Fig. 4) and suggests that this model bias is caused by the lower resolution of the chemistry model compared to the aerosol model in IFS.

Model mean bias and RMSE during the period of the fires is presented in Table 7. For this evaluation the observations (and model results) from Moscow and Zvenigorod have been combined for the day that both stations delivered data.

The mean bias of D+0 hindcasts improve with application of data assimilation (a reduction by $40 \%$ ) but more effectively when using GFAS emissions (90\% reduction). Best performance is obtained in runs Assim-GFAS, with a negligible mean bias. For hindcast days D+1 to D+3 the degradation in performance compared to D+0 is relatively moderate for all runs. Run Assim-GFAS remains best up to D+3, which is again different from the evaluation of ground-based AOD. Especially the fact that the RMSE does not degrade for the runs with GFAS could indicate that the available observations do not fully constrain the model performance. Unfortunately, for specific days with large discrepancies between $\mathrm{D}+0$ and $\mathrm{D}+3$ forecasts (e.g. on 7-8 August, not shown) there are no observations.

Table 8 provides the temporal correlation of the hindcasts with respect to these observations. This is best for run $\operatorname{Assim}\left(r^{2}=0.68, n=21\right.$ for hindcast $\left.\mathrm{D}+0\right)$, while the correlation for the runs with GFAS emissions is worse (D+0) or marginally better (D+1 to D+3) compared to CNT. Note that the limited number of observations and the observational 


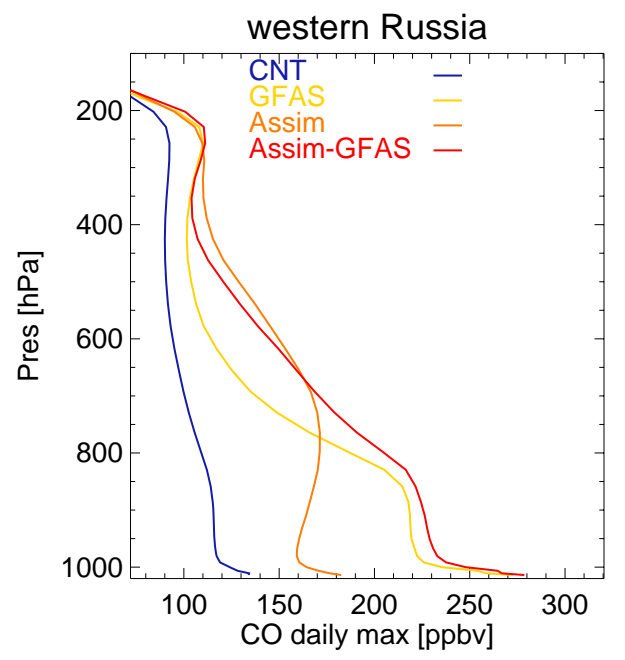

Fig. 8. Averaged daily maximum $\mathrm{CO}$ profiles for the four hindcast runs, at D+0 over western Russia, for the time period 20 July-15 August.

Table 8. Temporal correlation $\left(\mathrm{r}^{2}\right)$ of modeled total CO columns (units $10^{18}$ molec $\mathrm{cm}^{-2}$ ) with respect to ground-based CO total column observations at the Moscow and Zvenigorod stations between 20 July and 15 August $(n=21)$, as function of the hindcast day.

\begin{tabular}{lllll}
\hline Model & \multicolumn{5}{c}{$r^{2}$} \\
\hline & D+0 & D+1 & D+2 & D+3 \\
CNT & 0.32 & 0.26 & 0.28 & 0.33 \\
GFAS & 0.25 & 0.37 & 0.53 & 0.43 \\
Assim & 0.68 & 0.51 & 0.62 & 0.57 \\
Assim-GFAS & 0.31 & 0.48 & 0.59 & 0.48 \\
\hline
\end{tabular}

data gaps during this event degrade the representativeness of this score. This may also explain the atypical results of the higher $r^{2}$ for hindcasts $\mathrm{D}+1$ to $\mathrm{D}+3$ compared to $\mathrm{D}+0$ for runs with GFAS.

The difference in performance against ground-based and space based observations is illustrated by the area-average vertical model profiles (Fig. 8). The impact of the $\mathrm{CO}$ assimilation in run Assim is visible throughout the full troposphere, up to $200 \mathrm{hPa}$, with the largest increase in $\mathrm{CO}$ concentrations at around $700 \mathrm{hPa}$. In contrast, the runs with GFAS show high CO concentrations up to $\sim 800 \mathrm{hPa}$, corresponding to the injection height distribution of the $\mathrm{CO}$ emissions. Switching on the assimilation in run Assim-GFAS results in a marginal increase of the high concentrations in the boundary layer, and hence a little difference in $\mathrm{CO}$ total column with respect to ground-based observations, where the sensitivity of these instruments is maximal. But a more effective increase compared to run GFAS is found between 800 and $400 \mathrm{hPa}$, which explains the removal of the negative bias with respect to MOPITT.

\subsubsection{Tropospheric ozone}

We use IASI $\mathrm{O}_{3}$ partial tropospheric columns $(0-6 \mathrm{~km})$ from LISA (Dufour et al., 2012) to evaluate hindcasts of tropospheric $\mathrm{O}_{3}$ concentrations. The $\mathrm{O}_{3}$ data consist of a profile retrieval using the radiative transfer model KOPRA (Karlsruhe Optimised and Precise Radiative transfer Algorithm, (Stiller et al., 2000)) and its inversion module KOPRAFIT (Eremenko et al., 2008). Note that the IASI observations are filtered for cloud contamination before the retrieval. This filter should allow also screening for the worst aerosol contaminated pixels. However, the retrieval algorithm does not account for aerosol concentrations, and moderate aerosol loading can potentially introduce significant biases in the ozone retrieval depending on the type, size, altitude and amount of aerosols. For this study we have added an additional filter that corresponds to a noise level of about $70 \mathrm{nW} /\left(\mathrm{cm}^{2} \mathrm{~cm}^{-1} \mathrm{sr}\right)$ on the radiance measured by IASI in order to discard the data with too poor fit quality. Compared to the standard measurement noise level of about $20 \mathrm{nW} /\left(\mathrm{cm}^{2} \mathrm{~cm}^{-1} \mathrm{sr}\right)$ this significantly reduced spurious high tropospheric $\mathrm{O}_{3}$ columns over Kazakhstan, while it did not change columns elsewhere. The product used here was available for Europe and western Russia up to $58^{\circ} \mathrm{E}$. The retrieval error is estimated in the range of $10-20 \%$ (Dufour et al., 2012). In the validation procedure we map spatially and temporally interpolated model profiles to the instantaneous IASI observations at approx. 10:30 local time and then apply the averaging kernels.

In Fig. 9 we present maps of mean tropospheric $\mathrm{O}_{3}$ partial columns. On average the model runs are all well in line with IASI over western Europe, and show a slightly high bias over the Mediterranean region. All runs show lower ozone columns south-east of Moscow and particularly over western Kazakhstan than observed by IASI. The reasons for this are not fully understood. Although no strong wildfires took place here, the heat wave extended into this region, with daytime maximum temperatures reaching $40^{\circ} \mathrm{C}$ in the first two weeks of August. This resulted in a reduction in ozone dry deposition flux due to low soil wetness levels. The model might additionally suffer from the same shortcomings as suggested in the evaluation of the 2003 heat wave over western Europe (Ordóñez et al., 2010), i.e., the impact of high temperatures and increased solar radiation on the biogenic emissions (e.g. Lee et al., 2006; Solberg et al., 2008), which, together with moderately high $\mathrm{NO}_{\mathrm{x}}$ concentrations, can increase $\mathrm{O}_{3}$ production. On the other hand, an assessment of the local climatological biogenic VOC and soil $\mathrm{NO}_{\mathrm{x}}$ emissions as applied in current runs (Lathière et al., 2006) show that these are significantly larger in comparison to climatological emissions derived from MEGANv2 (Guenther et al., 2006), which constrains the possibility of an underestimation of ozone precursor emissions. Furthermore, a possible positive bias in the IASI retrieval could also contribute to the discrepancy between the model and observations. This bias could be caused by spectral interferences between ozone 

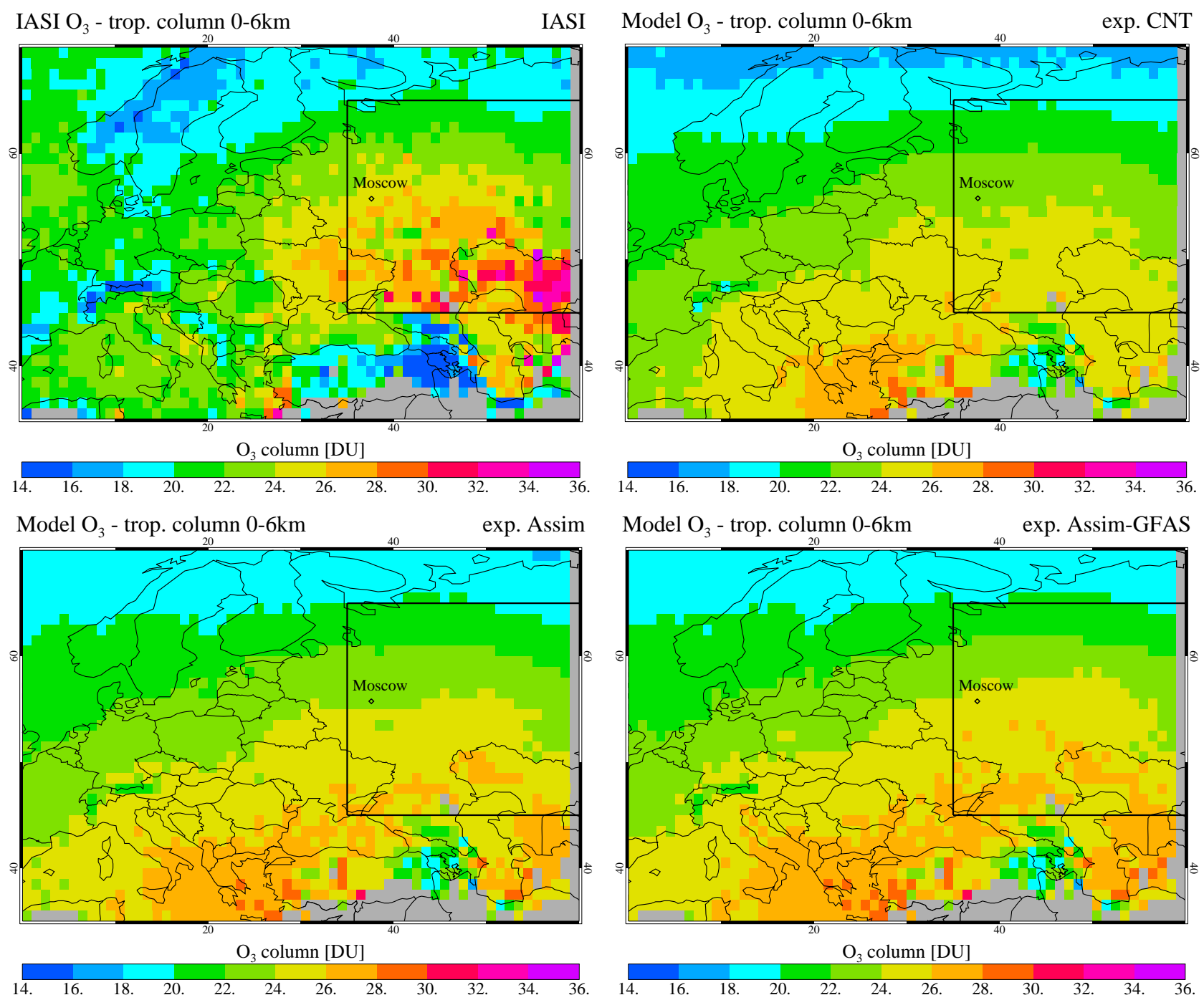

Fig. 9. Maps of mean $\mathrm{O}_{3}$ tropospheric partial columns $(0-6 \mathrm{~km})$ as observed from IASI between 20 July and 15 August 2010 compared to the kernel-weighted D+0 columns from the runs CNT, Assim and Assim-GFAS.

Table 9. Mean bias and RMSE of modeled $\mathrm{O}_{3}$ partial columns $(0-6 \mathrm{~km})$ in DU, compared to IASI $\mathrm{O}_{3}$ observations over western Russia between 20 July and 15 August, as function of the hindcast day.

\begin{tabular}{lrrrrllll}
\hline \multicolumn{1}{c}{ Model } & \multicolumn{4}{c}{ Bias } & \multicolumn{4}{c}{ RMSE } \\
\hline & $\mathrm{D}+0$ & $\mathrm{D}+1$ & $\mathrm{D}+2$ & $\mathrm{D}+3$ & $\mathrm{D}+0$ & $\mathrm{D}+1$ & $\mathrm{D}+2$ & $\mathrm{D}+3$ \\
CNT & -1.5 & -1.5 & -1.5 & -1.6 & 1.8 & 1.8 & 1.8 & 1.8 \\
GFAS & -0.6 & -0.6 & -0.7 & -0.7 & 1.7 & 1.7 & 1.7 & 1.7 \\
Assim & -1.0 & -1.1 & -1.2 & -1.3 & 1.7 & 1.7 & 1.7 & 1.8 \\
Assim-GFAS & -0.5 & -0.6 & -0.7 & -0.8 & 1.7 & 1.7 & 1.7 & 1.7 \\
\hline
\end{tabular}

and aerosols and/or water vapor. We note that the positive bias in IASI was reduced by applying a more strict error criterion as discussed above.

Nevertheless, the large-scale spatial patterns are captured by the model, including the north-south gradient in $\mathrm{O}_{3}$ columns over western Russia. Local differences between the runs are less than approx. 2 DU.

Figure 10 shows the time evolution of the corresponding area-mean tropospheric $\mathrm{O}_{3}$ columns for hindcasts $\mathrm{D}+0$. It illustrates that all model runs are able to capture the increase in $\mathrm{O}_{3}$ columns at the beginning of August, as well as the 


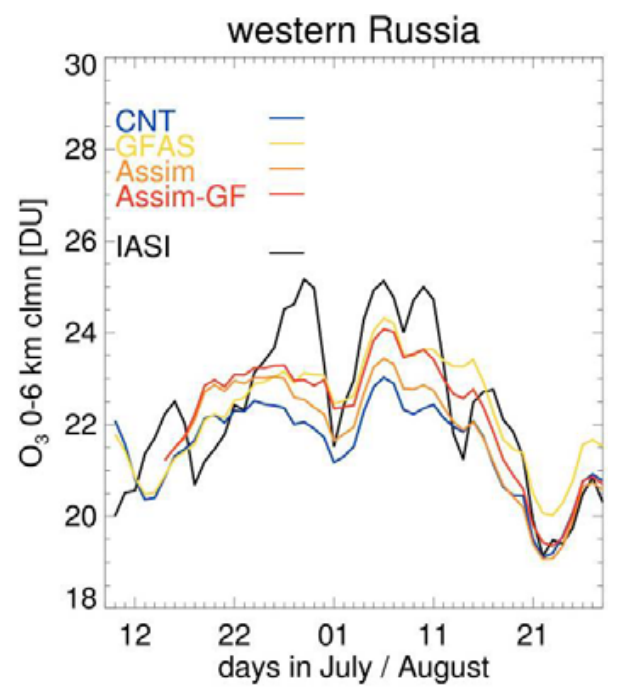

Fig. 10. Time series of modeled tropospheric $\mathrm{O}_{3}$ columns (hindcast $\mathrm{D}+0)$ with averaging kernel against IASI $\mathrm{O}_{3}$ columns $(0-6 \mathrm{~km})$. Data are smoothed over a 3-day time window to filter out variations in spatial coverage.
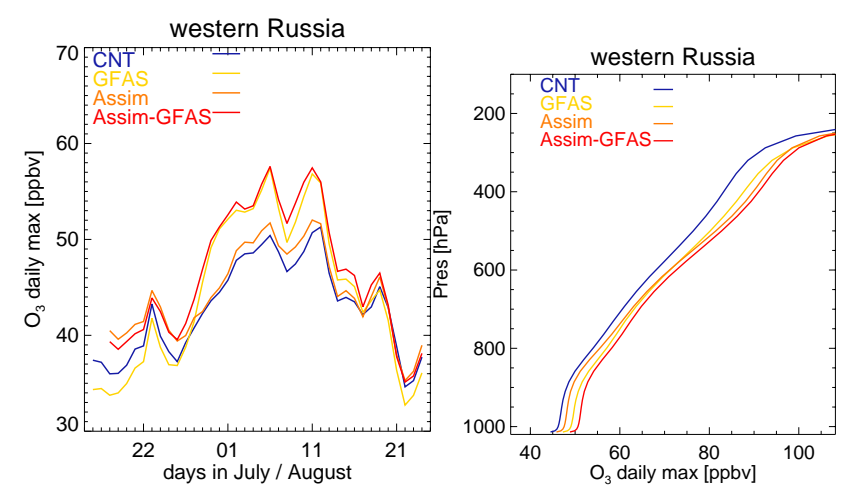

Fig. 11. (left) Maximum area-average surface $\mathrm{O}_{3}$ concentrations over western Russia for the four model settings, hindcast D+0. (right) corresponding time averaged profile of ozone daily maximum concentrations between 20 July and 15 August.

strong decrease between 10 and 21 August, the end of the heat wave. However, all model runs show a negative bias of approx. 1-3 DU with respect to IASI during the heat wave. It is largest for run CNT, and lowest for the runs that apply the GFAS emissions, indicating its positive impact on the ozone chemistry in the model.

The spatial variability in the instantaneous ozone columns is significantly larger for the IASI retrieval than in the model. While the daily average standard deviation of the IASI $\mathrm{O}_{3}$ observations over western Russia between 20 July and 15 August is $3.1 \mathrm{DU}$, it is only between 1.2 and 1.3 DU for the different hindcast runs. Part of this larger standard deviation in IASI columns can be explained by retrieval errors, estimated to be $\sim 2.5 \mathrm{DU}$ for the given time period and region. A lack of variability in the modeled $\mathrm{O}_{3}$ concentra- tions in the free troposphere additionally explains this discrepancy. These two factors contribute to the RMSE of the model against the IASI observations, which is about $1.7 \mathrm{DU}$, see Table 9. Although the use of assimilation helps to reduce the model bias, the largest improvement is a result of the use of the GFAS emissions, with a reduction of the mean bias by approx. $60 \%$ compared to the control run for D+0. The relative difference between the mean biases of the different hindcast runs is similar for all hindcast days, indicating the lasting effect of both initialization by assimilated fields as well as the use of GFAS emissions.

Despite the rather similar results for tropospheric $\mathrm{O}_{3}$ columns from the various runs, there are significant differences in the planetary boundary layer (PBL). Figure 11 shows that surface $\mathrm{O}_{3}$ concentrations are only slightly affected by the initialization from assimilation, while they are enhanced by $\sim 15 \%$ when using the GFAS emissions during the time of the fires. Moreover the figure illustrates that hindcasts using the GFAS emissions lead to elevated $\mathrm{O}_{3}$ levels throughout the troposphere while the assimilation has the largest impact at altitude levels between 600 and $300 \mathrm{hPa}$, and the smallest in the PBL, similar to what was found for $\mathrm{CO}$. Irrespective of the missing effects of the aerosols, which would presumably lead to a reduction in surface ozone concentrations (Konovalov et al. 2011), this shows the relevance of the NRT emission estimates on the modeling of ozone concentrations in the PBL, compared to the impact of ozone assimilation.

\subsubsection{Tropospheric nitrogen dioxide}

We compare hindcasts of tropospheric $\mathrm{NO}_{2}$ columns against the IUP Bremen SCIAMACHY $\mathrm{NO}_{2}$ product. Airmass factors determined from radiative transfer calculations are used to convert slant to vertical columns (Richter et al., 2005). $\mathrm{NO}_{2}$ tropospheric columns are only determined for clear sky pixels, a selection performed according to FRESCO data (Koelemeijer et al., 2001, 2002) for cloud fractions smaller than $20 \%$. Model data coinciding in time and space with SCIAMACHY measurements are used. The hindcasts are further compared to the DOMINO product v2.0 (Boersma et al., 2011), applying the same selection criteria as for SCIAMACHY, see also Huijnen et al. (2010b). The uncertainty in individual retrievals due to spectral fitting is $0.7 \times 10^{15}$ molecules $\mathrm{cm}^{-2}$ (Boersma et al., 2007). Note that the same $\mathrm{OMI} \mathrm{NO}$ column data over Eurasia were also used in the assimilation system, to provide initial conditions for the runs Assim and Assim-GFAS. Leitao et al. (2010) show that the sensitivity of $\mathrm{NO}_{2}$ satellite measurements can be increased or decreased, depending on the amount and optical properties of the aerosols, and its vertical distribution relative to that of $\mathrm{NO}_{2}$. Thus, it is difficult to estimate precisely the uncertainties associated with the retrieved tropospheric $\mathrm{NO}_{2}$ columns from SCIAMACHY measurements for this event. Note that there are significant differences between the 

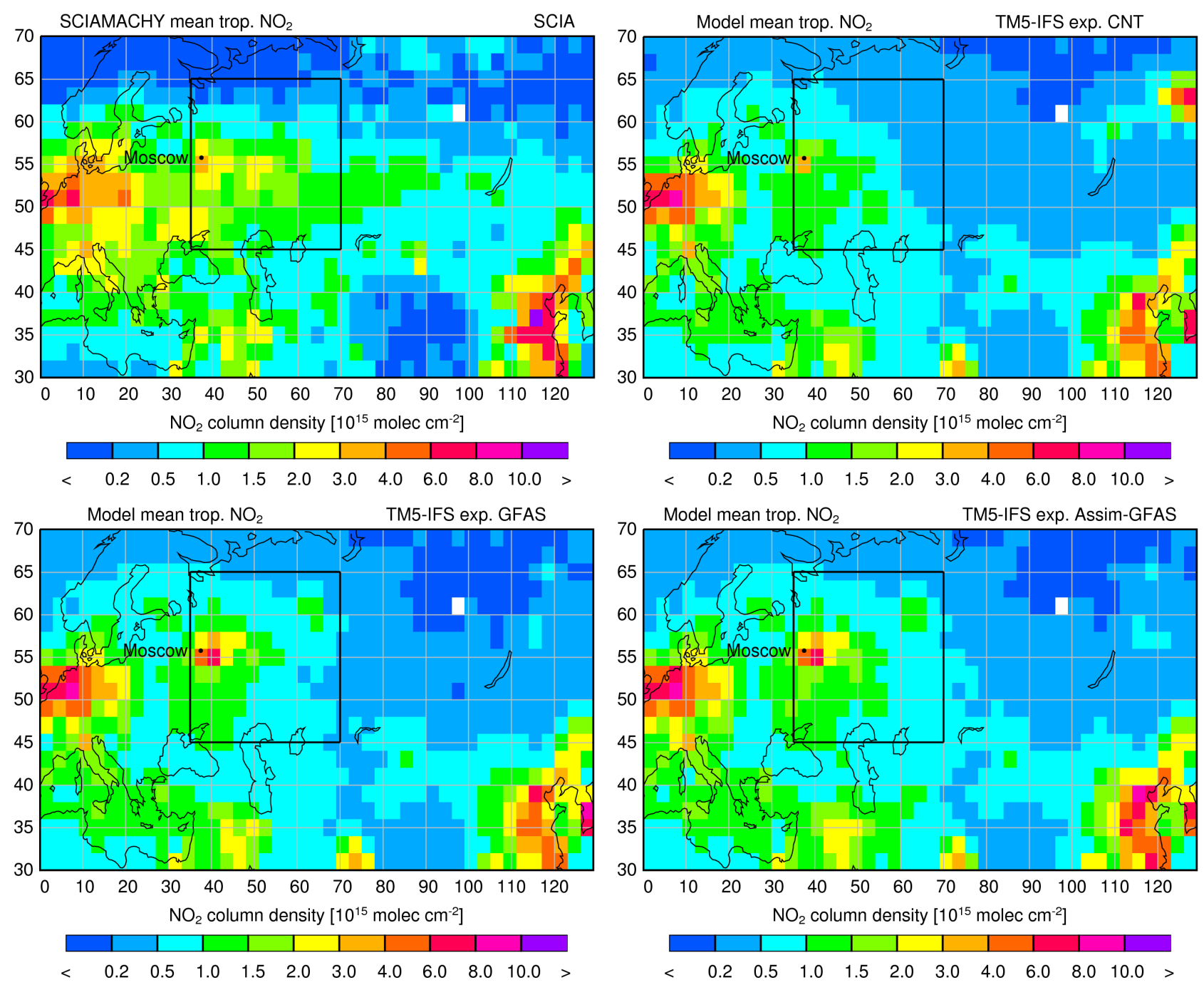

Fig. 12. Maps of mean tropospheric $\mathrm{NO}_{2}$ columns as observed from SCIAMACHY between 20 July and 15 August compared to the D+0 columns from the runs CNT, GFAS and Assim-GFAS.
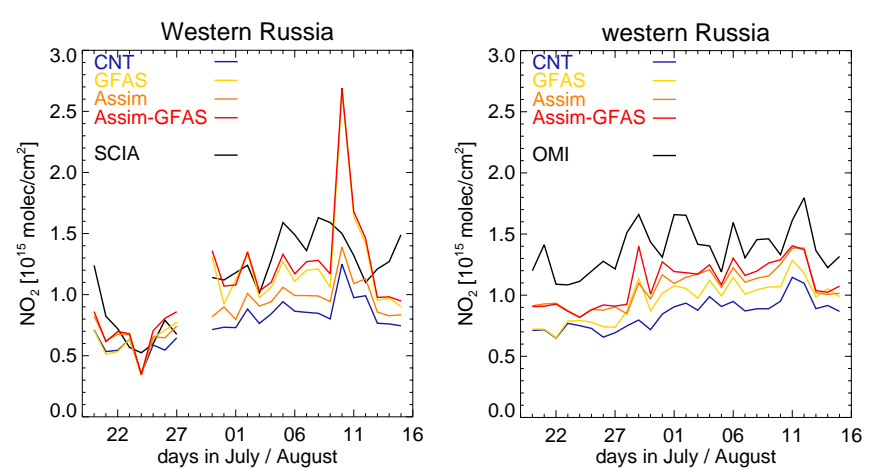

Fig. 13. Time series of modeled tropospheric $\mathrm{NO}_{2}$ columns (hindcast D+0) against SCIAMACHY (left) and with averaging kernel against $\mathrm{OMI} \mathrm{NO}_{2}$ from DOMINO v2.0 (right).
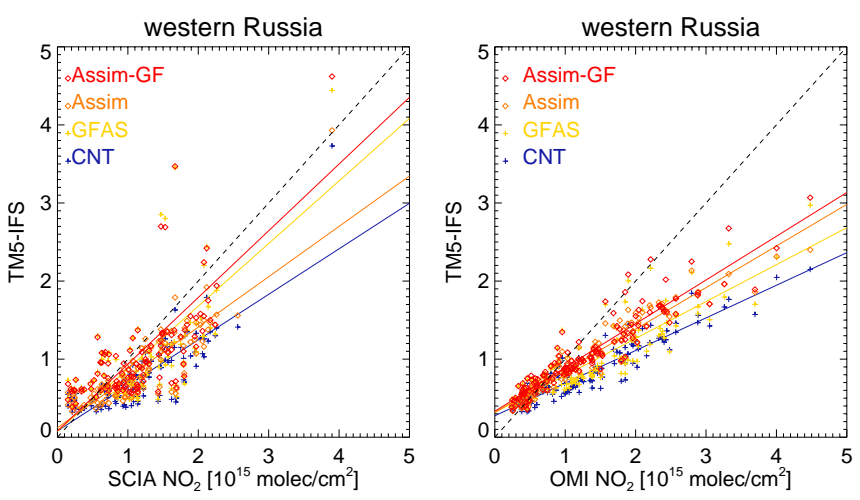

Fig. 14. Scatter plots of mean tropospheric $\mathrm{NO}_{2}$ for model runs at $\mathrm{D}+0$ with respect to observations from SCIAMACHY and OMI, for the period 20 July to 15 August 2010. 
DOMINO v2.0 and Bremen SCIAMACHY $\mathrm{NO}_{2}$ retrieval products. This includes, for example, the different overpass time (SCIAMACHY in the morning, OMI in the afternoon), and the fact that for the comparison to $\mathrm{OMI} \mathrm{NO}_{2}$ we apply averaging kernels to the model, while these are not used for the comparison to SCIAMACHY. Also, differences in the coverage (better for OMI) and resolution (better for OMI) result in more observations per model gridbox for OMI.

In general, the various model runs compare well with the SCIAMACHY measurements over western Russia, see Fig. 12. A hot-spot of high $\mathrm{NO}_{2}$ columns is observed within the gridbox containing Moscow, which can mainly be attributed to anthropogenic emissions. Both the SCIAMACHY and OMI instruments detect a large region of intensified $\mathrm{NO}_{2}$ spreading east of Moscow that is not simulated by any of the hindcast runs. Considering the size of this region this deficiency in the model simulations could point at uncertainties in the soil $\mathrm{NO}_{\mathrm{x}}$ emissions. In the current inventory these contribute to $\sim 20 \%$ of the total emissions in run GFAS (see Table 3).

In the surroundings of Moscow both SCIAMACHY and OMI show enhanced $\mathrm{NO}_{2}$ columns that may be attributed to fire emissions. The hindcast run GFAS has on average higher columns compared to CNT within this region. However, run GFAS shows the spots of high $\mathrm{NO}_{2}$ columns at different locations than observed from the satellite instruments. When switching on the initialization from assimilation, the $\mathrm{NO}_{2}$ columns over western Russia increase on average, thereby reducing the negative model bias. This is most visible in the region extending south and east of Moscow.

Figure 13 shows the time evolution of the model versions compared to the SCIAMACHY and OMI $\mathrm{NO}_{2}$ products. As we evaluate tropospheric $\mathrm{NO}_{2}$ columns over the relatively large western Russia region the daily average increase in columns during the time of the fires is limited. SCIAMACHY shows enhanced columns during the beginning of August, while for OMI high $\mathrm{NO}_{2}$ columns during the first days of August over the fires region are compensated by relatively low columns elsewhere. In both figures the increase in daily average $\mathrm{NO}_{2}$ columns with GFAS emissions and assimilation is well visible, with both aspects resulting in better average agreement to the observations. Nevertheless, the correlation between the area-mean observations and corresponding model columns is limited. The variability in magnitude, both in the model columns and the retrieval, is larger with respect to SCIAMACHY data than to OMI data (see, e.g., the high model concentrations in the evaluation against SCIAMACHY on 10 August). This is a direct consequence of the lower data volume in SCIAMACHY compared to OMI.

The scatter plots presented in Fig. 14 reveal in more detail the spatial correlation between the different runs and the observations over western Russia. The corresponding correlations and slopes as derived from a linear regression are
Table 10. Slope and spatial correlation $\left(r^{2}\right)$ of modeled tropospheric $\mathrm{NO}_{2}$ columns for hindcast D+0 with respect to SCIAMACHY and OMI observations over western Russia between 20 July and $15 \mathrm{Au}-$ gust.

\begin{tabular}{lllll}
\hline model & \multicolumn{2}{c}{ Slope } & \multicolumn{2}{c}{$r^{2}$} \\
\hline & SCIA & OMI & SCIA & OMI \\
CNT & 0.58 & 0.42 & 0.68 & 0.89 \\
GFAS & 0.80 & 0.47 & 0.37 & 0.78 \\
Assim & 0.65 & 0.53 & 0.72 & 0.93 \\
Assim-GFAS & 0.85 & 0.56 & 0.43 & 0.87 \\
\hline
\end{tabular}

given in Table 10. The best correlations are obtained for the simulations with climatological emissions, indicating that the spatial distribution of the GFAS emissions indeed does not accurately reflect the actually observed variability in $\mathrm{NO}_{2}$ columns.

The largest outlier in the scatter plot against SCIAMACHY was obtained for the runs that use GFAS emissions and can be traced back to the model hindcast for 30 July. For this particular day emissions due to peat fires were extreme in a small region east of Moscow (see Fig. 2). Actual emissions for that day are highly uncertain as these were kept identical to the ones from the previous day (see Sect. 3.1).

The mean bias and RMSE for all hindcast days with respect to the SCIAMACHY and $\mathrm{OMI} \mathrm{NO}$ 2 products are given in Tables 11 and 12. As expected, the mean bias decreases by $75 \%(29 \%)$ against SCIAMACHY (OMI) when using the GFAS emissions, but the RMSE significantly increases for the comparison with SCIAMACHY, while it hardly changed for OMI. Note that differences in the coverage and resolution result in more daily observations per model gridbox for OMI data. Therefore the model RMSE with respect to SCIAMACHY, as calculated from daily mean observed fields at the model grid resolution, is more influenced by retrieval errors than with respect to OMI (Boersma et al., 2007). The remaining contribution to the RMSE can be attributed to a mismatch of the local emissions.

A reduction in the bias of $28 \%$ (47\%) compared to SCIAMACHY (OMI) is achieved when including the assimilation of $\mathrm{O}_{3}, \mathrm{CO}$ and $\mathrm{NO}_{2}$ observations for initialization. The assimilation also leads to a slight decrease of the RMSE, which can be explained by the improved mean bias. Considering the short lifetime of $\mathrm{NO}_{2}$, we cannot exclude that most of the impact of the assimilation on $\mathrm{NO}_{2}$ is indirect, via assimilation of $\mathrm{CO}$ and $\mathrm{O}_{3}$. This is also consistent with the persisting lower bias with increasing forecast length in the assimilation runs. The enhanced $\mathrm{CO}$ causes a reduced abundance of $\mathrm{OH}$ radicals in the troposphere (e.g., Duncan et al., 2003). This in turn inhibits the formation of nitric acid $\left(\mathrm{HNO}_{3}\right)$ by oxidation of $\mathrm{NO}_{2}$. More tropospheric $\mathrm{O}_{3}$ would furthermore lead to higher $\mathrm{NO}$ titration in favour of $\mathrm{NO}_{2}$ production. Indeed the $\mathrm{OH}$ concentrations over the Moscow gridbox during the 
Table 11. Mean bias and RMSE of modeled tropospheric $\mathrm{NO}_{2}$ columns (units $10^{15}$ molec $\mathrm{cm}^{-2}$ ), compared to SCIAMACHY observations over western Russia between 20 July and 15 August, as function of the hindcast day.

\begin{tabular}{lllllllll}
\hline Model & \multicolumn{4}{c}{ Bias } & \multicolumn{4}{c}{ RMSE } \\
\hline & D+0 & D+1 & D+2 & D+3 & D+0 & D+1 & D+2 & D+3 \\
CNT & -0.40 & -0.40 & -0.40 & -0.39 & 0.58 & 0.59 & 0.59 & 0.60 \\
GFAS & -0.10 & -0.15 & -0.15 & -0.12 & 0.94 & 0.89 & 0.91 & 0.99 \\
Assim & -0.29 & -0.33 & -0.35 & -0.36 & 0.56 & 0.57 & 0.58 & 0.59 \\
Assim-GFAS & -0.04 & -0.09 & -0.11 & -0.08 & 0.90 & 0.89 & 0.93 & 1.02 \\
\hline
\end{tabular}

Table 12. Mean bias and RMSE of modeled tropospheric $\mathrm{NO}_{2}$ columns (units $10^{15}$ molec $\mathrm{cm}^{-2}$ ), compared to OMI observations over western Russia between 20 July and 15 August, as function of the hindcast day.

\begin{tabular}{lllllllll}
\hline Run & \multicolumn{4}{c}{ Bias } & \multicolumn{4}{c}{ RMSE } \\
\hline & D+0 & D+1 & D+2 & D+3 & D+0 & D+1 & D+2 & D+3 \\
CNT & -0.34 & -0.34 & -0.34 & -0.32 & 0.44 & 0.43 & 0.43 & 0.44 \\
GFAS & -0.24 & -0.25 & -0.23 & -0.22 & 0.43 & 0.43 & 0.43 & 0.43 \\
Assim & -0.18 & -0.23 & -0.26 & -0.27 & 0.40 & 0.41 & 0.42 & 0.42 \\
Assim-GFAS & -0.16 & -0.20 & -0.21 & -0.21 & 0.40 & 0.41 & 0.42 & 0.43 \\
\hline
\end{tabular}

first 10 days in August decrease by approx. 5\% in the free troposphere in run Assim-GFAS versus run GFAS. Yet, the actual numbers vary considerably depending on the hindcast day, altitude level and location. Further work is needed to quantify and validate the indirect effects of the assimilation on the chemical composition.

\subsubsection{Formaldehyde}

The retrieval of HCHO columns from the SCIAMACHY instrument follows a similar approach as described in the previous subsection for $\mathrm{NO}_{2}$, and is further detailed in Wittrock (2006) and Wittrock et al. (2006). Offsets introduced by the solar reference measurements are compensated by normalizing the retrieved slant columns with a mean value of $3.5 \times 10^{15} \mathrm{molec}^{-2}$ in the region between $180^{\circ}-200^{\circ} \mathrm{E}$. Airmass factors are used to convert the slant to vertical columns. These are taken from pre-calculated values that assumed a variable tropospheric aerosol loading. However, these scenarios do not necessarily represent the conditions of the fire event analyzed in this study. This means that a more precise correction of aerosol effect could lead to higher HCHO columns retrieved from SCIAMACHY observations (Wittrock, 2006). One other aspect to consider is that the low coverage of satellite pixels for SCIAMACHY data (combined with the short period of the analysis) implies a small number of measurements available per model grid box. This leads to a relatively large uncertainty in the averaged data due to the noise in the individual measurements, which in combination with the offset correction for some cases results in negative $\mathrm{HCHO}$ columns. Considering the low coverage also no cloud screening is performed for $\mathrm{HCHO}$ retrievals. The uncertainty in the mean of the observations is estimated of the order $10^{16}$ molec $\mathrm{cm}^{-2}$ (Wittrock, 2006).

Figure 15 presents the modeled tropospheric $\mathrm{HCHO}$ columns and observations from SCIAMACHY. The SCIAMACHY data show significant scatter, as a direct consequence of the large uncertainty in the HCHO retrieval. All model versions show somewhat higher HCHO background concentrations than observed from SCIAMACHY, which may partly be related to the offset correction in SCIAMACHY. On the other hand, the SCIAMACHY HCHO columns show a distinct region of high HCHO columns east of Moscow. A similar hot-spot, although higher, is only identified in the model simulations where the updated GFAS emissions were considered. The indirect impact of the assimilation is marginal: HCHO columns are on average $\sim 0.3 \times 10^{15} \mathrm{molec} \mathrm{cm}^{-2}$ lower compared to runs without initialization from assimilation. This could be explained by the change in oxidative capacity in the model, related to the higher tropospheric $\mathrm{NO}_{\mathrm{x}}, \mathrm{CO}$ and $\mathrm{O}_{3}$. Still, a large difference between the model runs that use the GFAS emissions and satellite data can be perceived, with the model having both higher background values as well as a different magnitude and shape of the region with elevated HCHO levels. This difference can be explained by uncertainties in both the model and the observations.

Time series of daily mean HCHO columns as well as an evaluation of mean bias and RMSE between model and observations are in this case strongly influenced by the scatter in the observations and the outliers, due to the sparse amount of data and high uncertainty of individual observations. Therefore such an analysis does not lead to significant results. Here, we focus on the spatial correlation between 

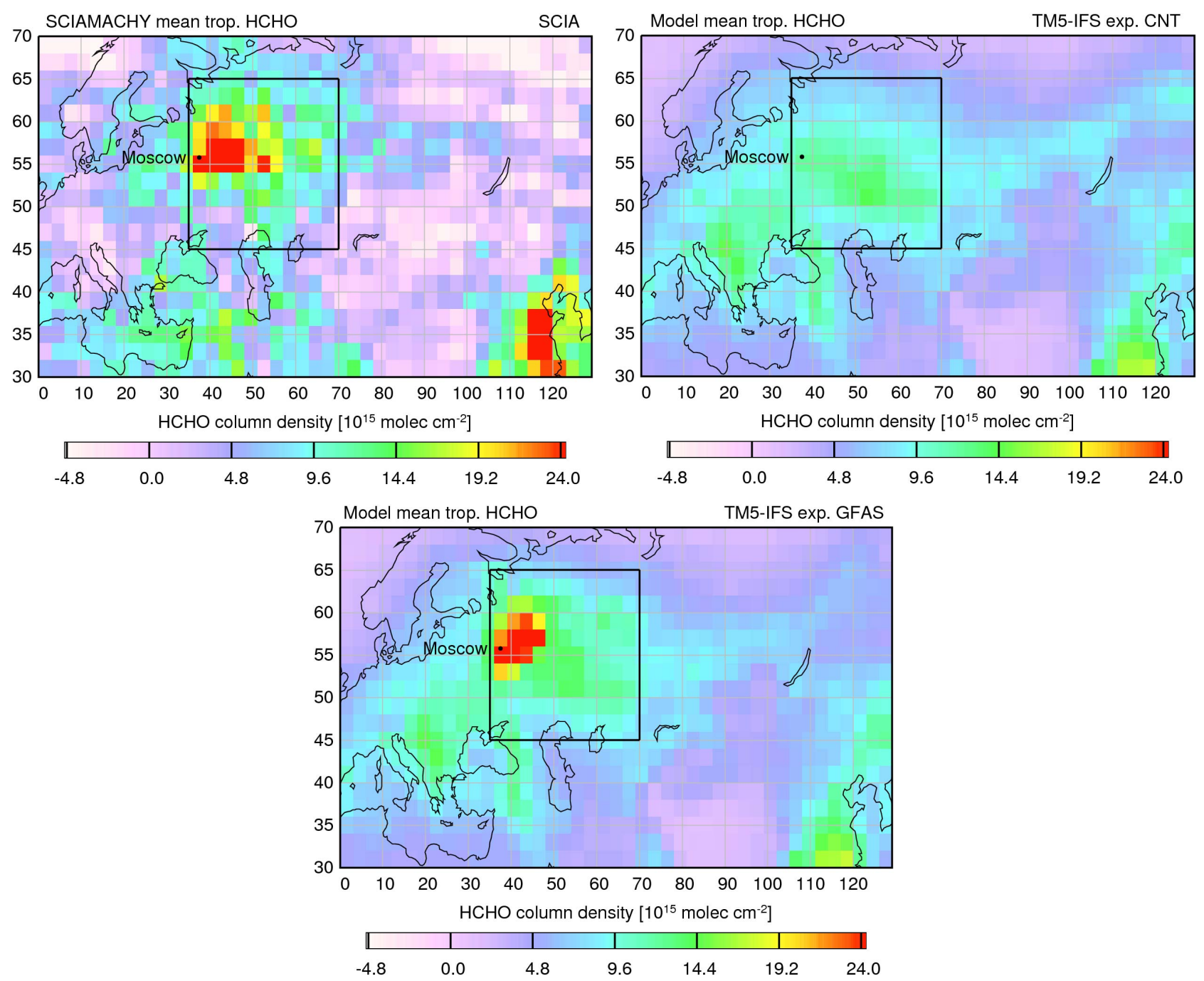

Fig. 15. Maps of mean tropospheric HCHO columns as observed from SCIAMACHY between 20 July and 15 August compared to the D+0 columns from the runs CNT and GFAS.

the model results and the SCIAMACHY observations. The HCHO scatter plot (Fig. 16) illustrates that, for the background concentrations, i.e., SCIAMACHY observations below $10^{16}$ molec $\mathrm{cm}^{-2}$, the model shows approximately constant HCHO columns of $10^{16}$ molec $\mathrm{cm}^{-2}$. Very similar results for the runs with/without assimilation are obtained. The presence of the region with high HCHO in the model runs with GFAS leads to a significant improvement in the slope of the regression and the correlation between the model and the SCIAMACHY observations, Table 13. This demonstrates the positive impact of the GFAS emissions on modeled HCHO columns. The large outlier in these runs with an average model column of $6.7 \times 10^{16}$ molec $\mathrm{cm}^{-2}$ is related to the peat fire emissions east of Moscow on 30 July, and corresponds to the outlier in the SCIAMACHY $\mathrm{NO}_{2}$ scatter plot.
Table 13. Slope and correlation $\left(r^{2}\right)$ of modeled HCHO columns for hindcast D+0 with respect to SCIAMACHY and OMI observations over western Russia between 20 July and 15 August.

\begin{tabular}{lll}
\hline model & Slope & $r^{2}$ \\
\hline CNT & 0.08 & 0.10 \\
GFAS & 0.68 & 0.47 \\
Assim & 0.07 & 0.08 \\
Assim-GFAS & 0.65 & 0.44 \\
\hline
\end{tabular}

\section{Integral assessment of GFAS emissions and assimilation on hindcasts}

In this section we assess the integral impact of both the GFASv1.0 emissions and initialization by assimilated trace gases on the atmospheric composition at $\mathrm{D}+0$, focusing on 


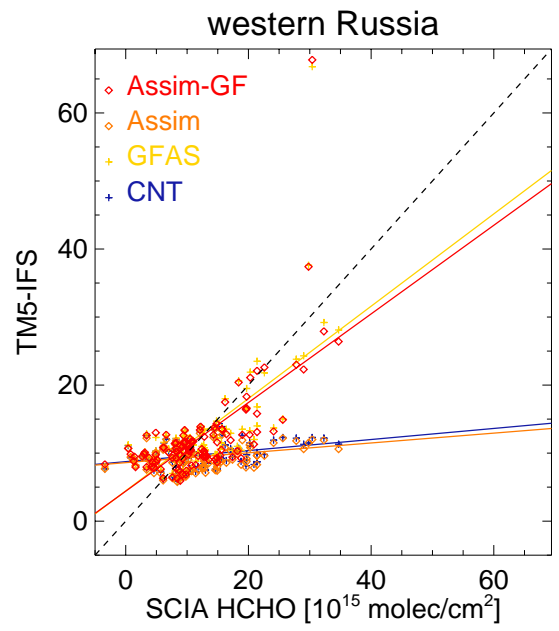

Fig. 16. Scatter plots of mean $\mathrm{HCHO}$ columns for model runs at $\mathrm{D}+0$ with respect to observations from SCIAMACHY, for the period 20 July to 15 August 2010.

the chemical interactions between the various trace gases. Also the implications of different start-conditions and emission estimates for the $\mathrm{D}+1$ to $\mathrm{D}+3$ hindcasts are analyzed.

\subsection{Impact of fire emissions on chemical production and loss budgets}

The impact on local production/loss budgets and the respective total masses (burdens) resulting from the application of the GFASv1.0 fire emissions as compared to the climatological emissions is given in Table 14. Note that the emission budgets include all contributing emission types in this region.

The modeled HCHO burden in run GFAS increases by $56 \%$, mainly due to the enhanced local HCHO emissions from GFASv1.0, but also because of enhanced oxidation of other hydrocarbons. Although the chemical production of $\mathrm{CO}$, which is mainly driven by $\mathrm{HCHO}$ oxidation, increases by $22 \%$ in run GFAS, the absolute contribution to the $\mathrm{CO}$ production remains small. About $4 \%$ of the extra $\mathrm{CO}$ production in run GFAS can be attributed to GFASv1.0 emissions of $\mathrm{HCHO}$ and other higher hydrocarbons. Thus, $96 \%$ of the increase in $\mathrm{CO}$ burden is attributed to the direct $\mathrm{CO}$ fire emissions. An indirect effect of the large GFASv1.0 emissions is an increase of $19 \%$ in the local CO lifetime, calculated as the local burden over the chemical loss. This corresponds to a lifetime of 1.5 month in run GFAS, and is hence a significant contributor to enhanced $\mathrm{CO}$ concentrations in the troposphere. The increase in CO lifetime is due to a reduction of the hydroxyl radical $(\mathrm{OH})$ concentration, which also explains the reduced $\mathrm{CH}_{4}$ oxidation budget. This is related to an increased scavenging of $\mathrm{OH}$ by the larger $\mathrm{CO}$ concentrations, as was discussed earlier by Duncan et al. (2003).

Additionally, the ozone chemical production and loss terms increase, related to larger $\mathrm{NO}_{\mathrm{x}}$ and $\mathrm{NMVOC}$ emissions due to the fires. Overall a net increase in tropospheric $\mathrm{O}_{3}$ burden of $4 \%$ is found. $\mathrm{O}_{3}$ concentrations are mostly enhanced in the PBL, see also Sect. 3.2. The dry deposition velocities in the two runs are identical, as they depend on meteorology only. Therefore the increase in $\mathrm{O}_{3}$ concentrations in the PBL explains the comparatively larger increase in $\mathrm{O}_{3}$ dry deposition flux by $10 \%$. As discussed earlier, the increase in the $\mathrm{O}_{3}$ burden is insufficient compared to the IASI observations, suggesting an under-estimation of ozone precursor gas emissions.

The mean biases in $\mathrm{NO}_{2}$ columns with respect to both SCIAMACHY and OMI, for the runs using the GFASv1.0 fire emissions, have improved significantly compared to the hindcast results with climatological emissions. This improvement suggests a general positive impact of higher $\mathrm{NO}_{\mathrm{x}}$ emissions on the model results. Nevertheless, the evaluation still indicates an under-estimation of $\mathrm{NO}_{\mathrm{x}}$ emissions, which could contribute to the low bias in $\mathrm{O}_{3}$.

Several authors suggested that an excess of aerosol concentrations will have an impact on chemical and photolysis rates, depending on aerosol microphysical and optical properties (e.g., Hodzic et al. 2007, Real et al., 2007, Verma et al., 2009). Konovalov et al. (2011) estimated that the neglect of shielding by an aerosol plume leads to a positive bias of $\sim 20-50 \%$ in $\mathrm{O}_{3}$ at the surface layer over Moscow, during most days in the intense fire period. This was explained by an overestimation of the ozone production by $\mathrm{NO}_{2}$ photolysis.

Overall we find that the increase in $\mathrm{O}_{3}$ burden and the larger $\mathrm{NO}_{\mathrm{x}}$-recycling are insufficient to counterbalance the larger $\mathrm{OH}$ scavenging by $\mathrm{CO}$. As we do not account for aerosol effects, the $\mathrm{O}_{3}$ production is likely over-estimated, as well as primary $\mathrm{OH}$ production due to the ozone photolysis. Correspondingly, this implies an over-estimation of the local $\mathrm{CH}_{4}$ and $\mathrm{CO}$ loss by oxidation. However, the magnitude of this effect is highly uncertain, depending on the actual aerosol optical parameters and the spatial and vertical distribution (Real et al., 2007). Also, while the effects can be very important on a local scale, as shown by Konovalov et al. (2011), their impact on the chemical budgets on a subcontinental scale is unclear, but likely small.

\subsection{Impact of assimilation on chemical composition}

The application of assimilation helps in most cases to reduce model biases. A small negative bias in $\mathrm{CO}$ with respect to MOPITT-V4 before and after the fire episode was found, whereas for days with the largest $\mathrm{CO}$ columns the hindcasts initialized with assimilated IASI CO show a high bias of approx. $0.5 \times 10^{18}$ molec $\mathrm{cm}^{-2}$. These biases are in line with an earlier evaluation for summer 2007 Greek fires (Turquety et al., 2009).

When switching on the assimilation of $\mathrm{O}_{3}$ total and partial stratospheric columns the negative $\mathrm{O}_{3}$ bias decreases by $33 \%$ compared to the control run, i.e., the impact is less than the 
Table 14. $\mathrm{CO}, \mathrm{HCHO}$ and $\mathrm{O}_{3}$ tropospheric chemical budgets in $\mathrm{Tg}$, for runs CNT and GFAS, and the relative change expressed as (GFAS-CNT)/(CNT), calculated for the period 15 July-5 August over western Russia. The imbalance in the $\mathrm{HCHO}, \mathrm{CO}$ and $\mathrm{O}_{3}$ budgets corresponds to the net mass change.

\begin{tabular}{lrrc}
\hline Model & CNT & GFAS & Difference [\%] \\
\hline HCHO emission & 0.14 & 0.24 & 71 \\
HCHO chem. prod & 1.85 & 2.25 & 16 \\
HCHO chem. loss & -1.80 & -2.23 & 22 \\
HCHO dry/wet deposition & -0.13 & -0.17 & 31 \\
HCHO net transport & -0.06 & -0.09 & - \\
HCHO burden & 0.016 & 0.025 & 56 \\
CO emission & 2.4 & 13.5 & 463 \\
CO chem. production & 1.8 & 2.2 & 22 \\
CO chem. loss & -2.2 & -2.9 & 32 \\
CO net transport & -2.2 & -14.0 & - \\
$\mathrm{CO}_{\text {burden }}$ & 2.8 & 4.4 & 57 \\
$\mathrm{CH}_{4}$ loss & 0.47 & 0.43 & -9 \\
$\mathrm{NO}_{\mathrm{x}} \mathrm{x}$ emission $(\mathrm{Tg} \mathrm{N})$ & 0.087 & 0.120 & 38 \\
$\mathrm{O}_{3}$ chem production & 6.8 & 8.4 & 24 \\
$\mathrm{O}_{3}$ chem loss & -4.9 & -5.5 & 12 \\
$\mathrm{O}_{3}$ dry deposition & -2.15 & -2.36 & 10 \\
$\mathrm{O}_{3}$ net transport & -0.1 & -1.0 & - \\
$\mathrm{O}_{3}$ burden & 3.64 & 3.80 & 4 \\
\hline
\end{tabular}

application of GFASv1.0. This is understandable because the highest sensitivity of the instruments that provide data used in the assimilation is to the stratosphere. For $\mathrm{NO}_{2}$ the assimilation is more effective, showing reductions in mean bias of $28 \%(47 \%)$ compared to SCIAMACHY (OMI). Also, the spatial correlation and the regression slope improve. Model $\mathrm{HCHO}$ columns are slightly lower with assimilation, as a consequence of a different oxidizing capacity of the atmosphere.

As in the current model runs $\mathrm{CO}, \mathrm{O}_{3}$ and $\mathrm{NO}_{2}$ are assimilated simultaneously, it is difficult to assess from the D+0 hindcasts the indirect impact of assimilation of one trace gas on the other, especially the interaction between $\mathrm{NO}_{2}$ assimilation and the other trace gases. Studying this effect requires separate sensitivity studies.

\section{3 impact of GFAS emissions and assimilation on D+1 to $D+3$ hindcasts}

Generally the D+1 to D+3 forecast accuracy decreases with increasing lead time, but its rate differs depending on the model version, trace gas and error metric. Run Assim shows generally lower RMSE at D+3 compared to run AssimGFAS, except for ground-based $\mathrm{CO}$ total columns and $\mathrm{O}_{3}$ total columns. Also RMSE in this run is always better than run CNT. The RMSE with respect to SCIAMACHY $\mathrm{NO}_{2}$ is $\sim 65 \%$ larger in the run with GFASv1.0 emissions at hindcast D+3 compared to the control run. This implies that initial conditions, and hence the application of data assimilation, is critical to the forecast accuracy in terms of RMSE, and additionally shows that the RMSE is sensitive to the temporal and spatial variability of the emissions, which is lower for the model with climatological emissions.

On the other hand, when forecast error is defined as an area-average mean bias on a regional scale, hindcasts that include the GFASv1.0 emissions show generally better accuracy than those that are only initialized with concentration fields from the assimilation. For instance, the mean bias in CO total columns is reduced by $84 \%$ at hindcast $\mathrm{D}+3$. This illustrates that the applied emission estimates become more relevant compared to the initialization, with increasing forecast time.

For $\mathrm{O}_{3}$, the RMSE and mean bias remain strongly linked to the values at hindcast $\mathrm{D}+0$, showing the lasting impact of the initial conditions. Also for $\mathrm{NO}_{2}$ the negative mean bias at hindcast $\mathrm{D}+3$ stays smaller in the runs with assimilation compared to those without. Considering the rather short lifetime for $\mathrm{NO}_{2}$ this suggests an indirect effect of the ozone and $\mathrm{CO}$ assimilation on $\mathrm{NO}_{2}$, possibly due to a persistently reduced abundance of $\mathrm{OH}$ radicals in the troposphere. Overall, best model performance is achieved with both assimilation and GFASv1.0 emissions switched on.

\section{Summary and conclusions}

Western Russia experienced a strong heat wave in the summer of 2010. Together with a drought, this resulted in severe wildfires which led to large-scale enhancements of trace gas and aerosol concentrations over several days. The fire emissions showed large variation in space and time, which aggravates the challenge to provide realistic forecasts of air pollution a few days in advance. In the framework of the MACC project a system has been developed for routine monitoring and forecasting of atmospheric composition on a global scale, whereby the meteorological data assimilation system at ECMWF has been extended with the assimilation of various reactive trace gases and aerosol optical depths. Fire emissions are available in near realtime from the GFASv1.0 system based on FRP data from the MODIS satellite instrument. We conducted a set of four model experiments with this system to quantify the effects of accurate and variable fire emissions and chemical data assimilation on the prediction of the chemical composition of the troposphere during July-August 2010 over western Russia. In the current setup the aerosols are calculated within the IFS, and the reactive gases based on the coupled IFS-TM5 system.

The total emission of $\mathrm{CO}$ for the period 16 July to $15 \mathrm{Au}-$ gust 2010 based on GFASv1.0 were $12.2 \mathrm{Tg}$ of $\mathrm{CO}$, which is about 11 times larger than the default emissions from a multi-annual climatology. An important factor for the accuracy of the fire emissions was the development of a detailed soil map for GFAS which contained the peatland areas east of Moscow, where some of the largest emissions originated 
from. Of the total $\mathrm{CO}$ emissions approx. $20 \%$ are attributed to peat fires. The GFASv1.0 CO emissions are $\sim 25 \%$ larger than estimated by Konovalov et al. (2011). Taking into account the large uncertainties in wildfire emissions, we consider the agreement between the two approaches encouraging.

The assessment of the $0-24 \mathrm{~h}$ hindcasts revealed that the impact of the GFASv1.0 emissions is dominant on the composition in the boundary layer, whereas the assimilation system changes concentrations more evenly distributed over the troposphere, reflecting the coarse vertical resolution of the averaging kernels and the error covariance matrices of the satellite data. For instance, data assimilation improved the negative mean bias to observed ground-based $\mathrm{CO}$ total columns, which are mostly sensitive to low-altitude CO, by $40 \%$ compared to the control run, while with the additional application of GFASv1.0 the mean bias became negligible.

Even though similar tropospheric $\mathrm{O}_{3}$ and $\mathrm{CO}$ columns were obtained with the assimilation system solely, the vertical attribution was highly dependent on the modeled first guess concentrations, and hence the fire emissions. Furthermore, besides the lack of vertical information, the assimilation of AOD encounters the difficulty of attributing the differences in observed and model AOD to the correct aerosol types. Therefore also the concentrations of the assimilated aerosol species were highly dependent on the modelled values. Actual fire emissions, which can change the ratio between, e.g., black carbon, sulphate and dust, are therefore crucial for the assimilation results. Hence the GFASv1.0 emissions complement the assimilation system in regions, altitudes and for trace gases or aerosol components that are not affected by the assimilation.

With application of GFASv1 emissions, the 0-24h hindcasts captured most of the individual events of high AOD, including the extreme event with values larger than 3 . Hindcasts of AOD, tropospheric $\mathrm{CO}, \mathrm{O}_{3}$ and $\mathrm{NO}_{2}$ columns showed improvement in mean biases with respect to observations of $87,63,60$ and $75 \%$, respectively, compared to the control run. By furthermore applying assimilation, the combined improvement for these compounds was 90, 87, 67 and $90 \%$. Better satellite observations, by increased accuracy and better spatial and temporal resolution, would be beneficial to further improve the accuracy of the $0-24 \mathrm{~h}$ hindcasts. Also a higher resolution for the chemical model will likely improve the performance on a local scale.

The application of GFASv1.0 emissions resulted in a constant bias in $\mathrm{CO}$ tropospheric columns of $-0.3 \times 10^{18}$ molec $\mathrm{cm}^{-2}$ against the MOPITT-V4 observations, before, during and after the main event. This suggests accurate GFASv1.0 emission totals for CO. Remaining biases, which are mostly resolved with the initialization from assimilation, may be explained by other missing emission sources or model deficiencies (Huijnen et al., 2010a). Despite the significant improvement in mean bias in $\mathrm{NO}_{2}$ columns with respect to SCIAMACHY compared to the control run, the RMSE and spatial correlation generally degraded with the application of GFASv1.0 emissions. This points at persisting local mismatches of the $\mathrm{NO}_{\mathrm{x}}$ emission estimates, relevant due to the relatively short lifetime of $\mathrm{NO}_{\mathrm{x}}$. Correlations between SCIAMACHY $\mathrm{HCHO}$ and model hindcasts improved from $r^{2}=0.10$ to $r^{2}=0.47$ when using GFASv1.0 emissions. The rather poor spatial correlation is caused by the large scatter and low coverage in the observed $\mathrm{HCHO}$ column data, as well as $\mathrm{HCHO}$ model uncertainties, such as biogenic $\mathrm{HCHO}$ and other VOC emissions.

With the forecast accuracy defined as an area-average mean bias, the GFASv1.0 emissions are positively contributing to the hindcasts up to 96 hour lead time, showing their relevance at the larger spatial scales. Furthermore, it is remarkable that the negative mean bias for $\mathrm{NO}_{2}$ remains smaller for all hindcast days in the runs with assimilation compared to those without. These results suggest a positive indirect effect of the assimilation of long lived tracers $\left(\mathrm{CO}\right.$ and $\left.\mathrm{O}_{3}\right)$ on short lived ones, like $\mathrm{NO}_{2}$.

On the other hand, the quality of local hindcasts depended strongly on the spatial distribution of fire emission and on the assumptions made for forecasted emissions. This was well visible from the relatively poor forecast accuracy quantified by the RMSE, as well as the temporal correlation with respect to ground-based CO total column data and AOD. The GFASv1.0 system simply propagates the observation-based emission estimates forward in time. This can lead to large overestimations of forecasted trace gas and aerosol concentrations when fire activity begins to subside after events of high emissions. In order to avoid false pollution alarms, a more sophisticated approach to forecast fire emissions based on the expected weather conditions and empirical analysis should be developed.

The combined analysis of fire radiative power observations, multiple trace gas and aerosol observations, as provided by the MACC system, result in a detailed quantitative description of the impact of major fires on atmospheric composition. Nevertheless, errors in the analysis remain significant for some trace gases, such as tropospheric ozone. Overall, this case study has demonstrated the capabilities of the MACC system to analyze air pollution during large-scale fire events and to forecast large-scale pollution plumes emanating from such fires. It highlights the necessity to maintain and improve the current capabilities for space-borne retrievals of trace gases, aerosols and fire radiative power.

Acknowledgements. We thank N. Chubarova and B. Holben and their staff for maintaining the Moscow AERONET site which provided data used in this investigation. Some of the satellite data were downloaded from the National Aeronautics and Space Administration (NASA) and the National Oceanic and Atmospheric Administration (NOAA). We acknowledge the free use of satellite retrieval data from www.temis.nl. D. Hurtmans, P. Coheur (ULB, Belgium) and C. Clerbaux, M. George (LATMOS, France) 
are acknowledged for scientific development, maintenance and distribution of the $\mathrm{CO}$ products from IASI, available from the Ether French atmospheric database (http://ether.ipsl.jussieu.fr). The work has been carried out within the MACC project, which is funded by the European Commission under the Seventh Research Framework Programme under contract number 218793.

Edited by: P. Monks

\section{References}

Akagi, S. K., Yokelson, R. J., Wiedinmyer, C., Alvarado, M. J., Reid, J. S., Karl, T., Crounse, J. D., and Wennberg, P. O.: Emission factors for open and domestic biomass burning for use in atmospheric models, Atmos. Chem. Phys., 11, 4039-4072, doi:10.5194/acp-11-4039-2011, 2011.

Andersson, E. and Järvinen, H.: Variational quality control, Q. J. Roy. Meteor. Soc., 125, 697-722, 1999.

Andreae, M. O. and Merlet, P. Emission of trace gases and aerosols from biomass burning. Global Biogeochem. Cy., 15, 955-966, 2001.

Benedetti, A., Morcrette, J.-J., Boucher, O., Dethof, A., Engelen, R., Fisher, M., Flentje, H., Huneeus, N., Jones, L., Kaiser, J., Kinne, S., Mangold, A., Razinger, M., Simmons, A., and Suttie, M.: Aerosol analysis and forecast in the European Centre for Medium-Range Weather Forecasts Integrated Forecast System: 2. Data assimilation, J. Geophys. Res., 114, D13205, doi:10.1029/2008JD011115, 2009.

Bhartia, P. K., McPeters, R. D., Mateer, C. L., Flynn, L. E., and Wellemeyer, C.: Algorithm for the estimation of vertical ozone profiles from the backscattered ultraviolet technique, J. Geophys. Res., 101, 18793-18806, 1996.

Boersma, K. F., Eskes, H. J., Veefkind, J. P., Brinksma, E. J., van der A, R. J., Sneep, M., van den Oord, G. H. J., Levelt, P. F., Stammes, P., Gleason, J. F., and Bucsela, E. J.: Near-real time retrieval of tropospheric NO2 from OMI, Atmos. Chem. Phys., 7, 2103-2118, doi:10.5194/acp-7-2103-2007, 2007.

Boersma, K. F., Eskes, H. J., Dirksen, R. J., van der A, R. J., Veefkind, J. P., Stammes, P., Huijnen, V., Kleipool, Q. L., Sneep, M., Claas, J., Leitão, J., Richter, A., Zhou, Y., and Brunner, D.: An improved tropospheric NO2 column retrieval algorithm for the Ozone Monitoring Instrument, Atmos. Meas. Tech., 4, 19051928, doi:10.5194/amt-4-1905-2011, 2011.

Chubarova, N., Nezval', Ye., Sviridenkov, I., Smirnov, A., and Slutsker, I.: Smoke aerosol and its radiative effects during extreme fire event over Central Russia in summer 2010, Atmos. Meas. Tech., 5, 557-568, doi:10.5194/amt-5-557-2012, 2012.

Deeter, M. N., Edwards, D. P., Gille, J. C., Emmons, L. K., Francis, G., Ho, S.-P., Mao, D., Masters, D., Worden, Drummond H. J. R., and Novelli, P. C.: The MOPITT version 4 CO product: Algorithm enhancements, validation, and long-term stability, J. Geophys. Res., 115, D07306, doi:10.1029/2009JD013005, 2010.

Dole, R., Hoerling, M., Perlwitz, J., Eischeid, J., Pegion, P., Zhang, T., Quan, X.-W., Xu, T., and Murray, D.: Was there a basis for anticipating the 2010 Russian heat wave?, Geophys. Res. Lett., 38, L06702, doi:10.1029/2010GL046582, 2011.

Dufour, G., Eremenko, M., Griesfeller, A., Barret, B., LeFlochmoën, E., Clerbaux, C., Hadji-Lazaro, J., Coheur, P.-F., and Hurtmans, D.: Validation of three different scientific ozone products retrieved from IASI spectra using ozonesondes, Atmos. Meas. Tech., 5, 611-630, doi:10.5194/amt-5-611-2012, 2012.

Duncan, B. N., Bey, I., Chin, M., Mickley, L. J., Fairlie, T. D., Martin, R. V., and Matsueda, H.: Indonesian wildfires of 1997: Impact on tropospheric chemistry, J. Geophys. Res., 108, 4458, doi:10.1029/2002JD003195, 2003.

Dupont, R., Pierce, B., Worden, J., Hair, J., Fenn, M., Hamer, P., Natarajan, M., Schaack, T., Lenzen, A., Apel, E., Dibb, J., Diskin, G., Huey, G., Weinheimer, A., Kondo, Y., and Knapp, D.: Attribution and evolution of ozone from Asian wild fires using satellite and aircraft measurements during the ARCTAS campaign, Atmos. Chem. Phys., 12, 169-188, doi:10.5194/acp-12169-2012, 2012.

Elansky, N., Mokhov, I., Belikov, I., Berezina, E., Elokhov, A.,Ivanov, V., Pankratova, N., Postylyakov, O., Safronov, A., Skorokhod, A., and Shumskii, R.: Gaseous admixtures in the atmosphere over Moscow during the 2010 summer, Izv. Atmos. Ocean. Phys., 47, doi:10.1134/S000143381106003X, 2011.

Elguindi, N., Clark, H., Ordóñez, C., Thouret, V., Flemming, J., Stein, O., Huijnen, V., Moinat, P., Inness, A., Peuch, V.-H., Stohl, A., Turquety, S., Athier, G., Cammas, J.-P., and Schultz, M.: Current status of the ability of the GEMS/MACC models to reproduce the tropospheric $\mathrm{CO}$ vertical distribution as measured by MOZAIC, Geosci. Model Dev., 3, 501-518, doi:10.5194/gmd-3501-2010, 2010.

Eremenko, M., Dufour, G., Forêt, G., Keim, C., Orphal, J., Beekmann, M., Bergametti, G., and Flaud, J.-M.: Tropospheric ozone distributions over Europe during the heat wave in July 2007 observed from infrared nadir spectra recorded by IASI, Geophys. Res. Lett., 35, L1885, doi:10.1029/2008GL034803, 2008.

Eskes, H. J. van der A, R. J., Brinksma, E. J., Veefkind, J. P., de Haan, J. F., and Valks, P. J. M.: Retrieval and validation of ozone columns derived from measurements of SCIAMACHY on Envisat, Atmos. Chem. Phys. Discuss, 5, 44294475, doi:10.5194/acpd-5-4429-2005, 2005.

FAO (Food and Agriculture Organization), WRB (World Reference Base) Map of World Soil Resources. Land and Water Development Division AGL, Food and Agriculture Organization of the United Nations, Rome, Italy, available online at http: //www.fao.org/ag/agl/agll/wrb/soilres.stm, last access: 2 January 2004, 2003.

Flemming, J., Inness, A., Flentje, H., Huijnen, V., Moinat, P., Schultz, M. G., and Stein, O.: Coupling global chemistry transport models to ECMWF's integrated forecast system, Geosci. Model Dev., 2, 253-265, doi:10.5194/gmd-2-253-2009, 2009.

Flemming, J., Inness, A., Jones, L., Eskes, H. J., Huijnen, V., Schultz, M. G., Stein, O., Cariolle, D., Kinnison, D., and Brasseur, G.: Forecasts and assimilation experiments of the Antarctic ozone hole 2008, Atmos. Chem. Phys., 11, 1961-1977, doi:10.5194/acp-11-1961-2011, 2011.

Fokeeva, E., Safronov, A., Rakitin, V., Yurganov, L., Grechko, E.,Shumskii, R.: Investigation of the 2010 July-August fires impact on carbon monoxide atmospheric pollution in Moscow and its outskirts, estimating of emissions. Izv. Atmos. Ocean. Phys. 47, 682-698, doi:10.1134/S0001433811060041, 2011.

George, M., Clerbaux, C., Hurtmans, D., Turquety, S., Coheur, P.F., Pommier, M., Hadji-Lazaro, J., Edwards, D. P., Worden, H., Luo, M., Rinsland, C., and McMillan, W.: Carbon monoxide dis- 
tributions from the IASI/METOP mission: evaluation with other space-borne remote sensors, Atmos. Chem. Phys., 9, 8317-8330, doi:10.5194/acp-9-8317-2009, 2009.

Grell, G. and Baklanov, A.: Integrated modeling for forecasting weather and air quality: A call for fully coupled approaches. Atmospheric Environment, 45, 6845-6851, ISSN 1352-2310, doi:10.1016/j.atmosenv.2011.01.017, 2011.

Guenther, A., Karl, T., Harley, P., Wiedinmyer, C., Palmer, P. I., and Geron, C.: Estimates of global terrestrial isoprene emissions using MEGAN (Model of Emissions of Gases and Aerosols from Nature), Atmos. Chem. Phys., 6, 3181-3210, doi:10.5194/acp-63181-2006, 2006.

Heil, A., Kaiser, J. W., van der Werf, G. R., Wooster, M. J., Schultz, M. G., and van der Gon, H. D.: Assessment of the real-time fire emissions (GFASv0) by MACC. Technical report 628, ECMWF, available at: http://www.ecmwf.int/publications/ library/do/references/show?id=89802, 2010.

Hodzic, A., Madronich, S., Bohn, B., Massie, S., Menut, L., and Wiedinmyer, C.: Wildfire particulate matter in Europe during summer 2003: meso-scale modeling of smoke emissions, transport and radiative effects, Atmos. Chem. Phys., 7, 4043-4064, doi:10.5194/acp-7-4043-2007, 2007.

Hollingsworth, A., Engelen, R. J., Textor, C., Benedetti, A., Boucher, O., Chevallier, F., Dethof, A., Elbern, H., Eskes, H., Flemming, J., Granier, C., Kaiser, J. W., Morcrette, J. J., Rayner, P., Peuch, V. H., Rouil, L., Schultz, M. G., Simmons, A. J., and The GEMS Consortium: The Global Earth-system Monitoring using Satellite and in-situ data (GEMS) Project: Towards a monitoring and forecasting system for atmospheric composition, BAMS, 89, 1147-1164, doi:10.1175/2008BAMS2355.1, 2008.

Huijnen, V., Williams, J., van Weele, M., van Noije, T., Krol, M., Dentener, F., Segers, A., Houweling, S., Peters, W., de Laat, J., Boersma, F., Bergamaschi, P., van Velthoven, P., Le Sager, P., Eskes, H., Alkemade, F., Scheele, R., Nédélec, P., and Pätz, H.-W.: The global chemistry transport model TM5: description and evaluation of the tropospheric chemistry version 3.0, Geosci. Model Dev., 3, 445-473, doi:10.5194/gmd-3-445-2010, 2010a.

Huijnen, V., Eskes, H. J., Poupkou, A., Elbern, H., Boersma, K. F., Foret, G., Sofiev, M., Valdebenito, A., Flemming, J., Stein, O., Gross, A., Robertson, L., D'Isidoro, M., Kioutsioukis, I., Friese, E., Amstrup, B., Bergstrom, R., Strunk, A., Vira, J., Zyryanov, D., Maurizi, A., Melas, D., Peuch, V.-H., and Zerefos, C.: Comparison of OMI NO2 tropospheric columns with an ensemble of global and European regional air quality models, Atmos. Chem. Phys., 10, 3273-3296, doi:10.5194/acp-10-3273-2010, $2010 \mathrm{~b}$.

Hurtmans D., Coheur, P.-F., Wespes, C., Clarisse, L., Scharf, O., Clerbaux, C., Hadji-Lazaro, J., George, M., and Turquety, S.: FORLI radiative transfer and retrieval code for IASI, J. Quant. Spectrosc. Ra. Transfer, 13, 1391-1408, doi:10.1016/j.jqst.2012.02.036, 2012.

Ichoku, C. and Kaufman, Y. J.: A method to derive smoke emission rates from MODIS fire radiative energy measurements, IEEE Geosci. Remote. Sci., 43, 2636-2649, 2005.

Inness, A., Flemming, J., Suttie, M. and Jones, L.: GEMS data assimilation system for chemically reactive gases, ECMWF Technical report 587, 2009.

Kaiser, J. W., Suttie, M., Flemming, J., Morcrette, J.-J., Boucher, O., and Schultz, M. G.: Global real-time fire emission estimates based on space-borne fire radiative power observations, AIP Conf. Proc., 1100, 645-648, doi:10.1063/1.3117069, 2009.

Kaiser, J. W., Heil, A., Andreae, M. O., Benedetti, A., Chubarova, N., Jones, L., Morcrette, J.-J., Razinger, M., Schultz, M. G., Suttie, M., and van der Werf, G. R.: Biomass burning emissions estimated with a global fire assimilation system based on observed fire radiative power, Biogeosciences, 9, 527-554, doi:10.5194/bg-9-527-2012, 2012.

Koelemeijer, R. B. A., Stammes, P., Hovenier, J. W., and de Haan, J. F.: A fast method for retrieval of cloud parameters using oxygen A-band measurements from the Global Ozone Monitoring Instrument, J. Geophys. Res., 106, 3475-3490, 2001.

Koelemeijer, R. B. A., Stammes, P., Hovenier, J. W., and de Haan, J. F.: Global distributions of effective cloud fraction and cloud top derived from oxygen A band spectra measured by the Global Ozone Monitoring Experiment: Comparison to ISCCP data, J. Geophys. Res., 107, 4151, doi:10.1029/2001JD000840, 2002.

Konovalov, I. B., Beekmann, M., Kuznetsova, I. N., Yurova, A., and Zvyagintsev, A. M.: Atmospheric impacts of the 2010 Russian wildfires: integrating modelling and measurements of an extreme air pollution episode in the Moscow region, Atmos. Chem. Phys., 11, 10031-10056, doi:10.5194/acp-11-10031-2011, 2011.

Lathière, J., Hauglustaine, D. A., Friend, A. D., De NobletDucoudré, N., Viovy, N., and Folberth, G. A.: Impact of climate variability and land use changes on global biogenic volatile organic compound emissions, Atmos. Chem. Phys., 6, 2129-2146, doi:10.5194/acp-6-2129-2006, 2006.

Lee, J. D., Lewis, A. C., Monks, P. S., Jacob, M. Hamilton, J. F., Hopkins, J. R., Watsona, N. M., Saxtona, J. E., Ennis, C., Carpenter, L. J. Carslaw, N., Fleming, Z., Bandy, B. J., Oram, D. E., Penkett, S. A., Slemr, J., Norton, E., Rickard, A. R., Whalley, L. K., Heard, D. E., Bloss, W. J., Gravestock, T., Smith, S. C., Stanton, J., Pilling, M. J., Jenkin, M. E.: Ozone photochemistry and elevated isoprene during the UK heatwave of August 2003, Atmos. Environ., 40, 7598-7613, 2006.

Leitão, J., Richter, A., Vrekoussis, M., Kokhanovsky, A., Zhang, Q. J., Beekmann, M., and Burrows, J. P.: On the improvement of $\mathrm{NO}_{2}$ satellite retrievals -aerosol impact on the airmass factors, Atmos. Meas. Tech., 3, 475-493, doi:10.5194/amt-3-475-2010, 2010.

Levelt, P. F., van den Oord, G. H. J., Dobber, M. R., Mälkki, A., Visser, H., de Vries, J., Stammes, P., Lundell, J. O. V., and Saari, H.: The Ozone Monitoring Instrument, IEEE T. Geosci. Remote, 44, 1093-1101, 2006.

Matsueda, M.: Predictability of Euro-Russian blocking in summer of 2010, Geophys. Res. Lett., 38, L06801, doi:10.1029/2010GL046557, 2011.

McMillan, W. W., Pierce, R. B., Sparling, L. C., Osterman, G., McCann, K., Fischer, M. L., Rappenglück, B., Newsom, R., Turner, D., Kittaka C., Evans, K., Biraud, S., Lefer, B., Andrews, A., and Oltmans, S.: An observational and modeling strategy to investigate the impact of remote sources on local air quality: A Houston, Texas, case study from the Second Texas Air Quality Study (TexAQS II), J. Geophys. Res., 115, D01301, doi:10.1029/2009JD011973, 2010.

Mebust, A. K., Russell, A. R., Hudman, R. C., Valin, L. C., and Cohen, R. C.: Characterization of wildfire NOx emissions using MODIS fire radiative power and OMI tropospheric NO2 columns, Atmos. Chem. Phys., 11, 5839-5851, doi:10.5194/acp- 
11-5839-2011, 2011.

Mei, L., Xue, Y., de Leeuw, G., Guang, J., Wang, Y., Li, Y., Xu, H., Yang, L., Hou, T., He, X., Wu, C., Dong, J., and Chen, Z.: Integration of remote sensing data and surface observations to estimate the impact of the Russian wildfires over Europe and Asia during August 2010, Biogeosciences, 8, 3771-3791, doi:10.5194/bg-8-3771-2011, 2011.

Menut, L. and Bessagnet, B.: Atmospheric composition forecasting in Europe, Ann. Geophys., 28, 61-74, doi:10.5194/angeo-28-612010, 2010.

Miller, D. J., Sun, K., Zondlo, M. A., Kanter, D., Dubovik, O., Welton, E. J., Winker, D. M., and Ginoux, P.: Assessing boreal forest fire smoke aerosol impacts on U.S. air quality: A case study using multiple data sets, J. Geophys. Res., 116, D22209, doi:10.1029/2011JD016170, 2011.

Morcrette, J. J., Boucher, O., Jones, L., Salmond, D., Bechtold, P., Beljaars, A., Benedetti, A., Bonet, A., Kaiser, J.W., Razinger, M., Schulz, M., Serrar, S., Simmons, A. J., Sofiev, M., Suttie, M., Tompkins, A. M., and Untch, A.: Aerosol analysis and forecast in the European Centre for Medium-RangeWeather Forecasts Integrated Forecast System: Forward modeling, J. Geophys. Res.Atmos., 114, D06206, doi:10.1029/2008JD011235, 2009.

Ordóñez, C., Elguindi, N., Stein, O., Huijnen, V., Flemming, J., Inness, A., Flentje, H., Katragkou, E., Moinat, P., Peuch, V.-H., Segers, A., Thouret, V., Athier, G., van Weele, M., Zerefos, C. S., Cammas, J.-P., and Schultz, M. G.: Global model simulations of air pollution during the 2003 European heat wave, Atmos. Chem. Phys., 10, 789-815, doi:10.5194/acp-10-789-2010, 2010.

Parrish, D. F. and Derber, J. C.: The National Meteorological Center's spectral statistical-interpolation analysis scheme. Mon. Weather Rev., 120, 1747-1763, 1992.

Pfister, G. G., Parrish, D. D., Worden, H., Emmons, L. K., Edwards, D. P., Wiedinmyer, C., Diskin, G. S., Huey, G., Oltmans, S. J., Thouret, V., Weinheimer, A., and Wisthaler, A.: Characterizing summertime chemical boundary conditions for airmasses entering the US West Coast, Atmos. Chem. Phys., 11, 1769-1790, doi:10.5194/acp-11-1769-2011, 2011.

Real, E., Law, K. S., Weinzierl, B., Fiebig, M., Petzold, A. Wild, O. Methven, J. , Arnold, S., Stohl, A., Huntrieser, H., Roiger, A., Schlager, H., Stewart, D., Avery, M., Sachse, G., Browell, E., Ferrare, R., and Blake, D.: Processes influencing ozone levels in Alaskan forest fire plumes during longrange transport over the North Atlantic, J. Geophys. Res., 112, D10S41, doi:10.1029/2006JD007576, 2007.

Redler, R., Valcke, S., and Ritzdorf, H.: OASIS4 - a coupling software for next generation earth system modelling, Geosci. Model Dev., 3, 87-104, doi:10.5194/gmd-3-87-2010, 2010.

Remer, L. A., Kaufman, Y. J., Tanré, D. Mattoo, S. Chu, D. A, Martins, J. V. Li, R.-R. Ichoku, C. Levy, R. C., Kleidman, R. G., Eck, F. Vermote, E. and Holben, B. N.: The MODIS Aerosol Algorithm, Products, and Validation. J. Atmos. Sci., 62, 947-973. doi:10.1175/JAS3385.1, 2005.

Richter, A., Burrows, J. P., Nüß, H., Granier, C., and Niemeier, U.: Increase in tropospheric nitrogen dioxide levels over China observed from space, Nature, 437, 129-132, 2005.

Sandu, A. and Chai, T.: Chemical Data Assimilation - An Overview, Atmosphere, 2, 426-463; doi:10.3390/atmos2030426, 2011.
Schultz, M. G., Backman, L., Balkanski, Y., Bjoerndalsaeter, S., Brand, R., Burrows, J. P., Dalsoeren, S., de Vasconcelos, M., Grodtmann, B., Hauglustaine, D. A., Heil, A., Hoelzemann, J. J., Isaksen, I. S. A., Kaurola, J., Knorr, W., Ladstaetter- Weissenmayer, A., Mota, B., Oom, D., Pacyna, J., Panasiuk, D., Pereira, J. M. C., Pulles, T., Pyle, J., Rast, S., Richter, A., Savage, N., Schnadt, C., Schulz, M., Spessa, A., Staehelin, J., Sundet, J. K., Szopa, S., Thonicke, K., van het Bolscher, M., van Noije, T., van Velthoven, P., Vik, A. F., and Wittrock, F.: REanalysis of the TROpospheric chemical composition over the past 40 years (RETRO) - A long-term global modeling study of tropospheric chemistry, Final Report, Jülich/Hamburg, Germany, 2007 (Published as report no. 48/2007 in the series "Reports on Earth System Science" of the Max Planck Institute for Meteorology, Hamburg, ISSN1614-1199), 2007.

Sofiev, M., Vankevich, R., Lotjonen, M., Prank, M., Petukhov, V., Ermakova, T., Koskinen, J., and Kukkonen, J.: An operational system for the assimilation of the satellite information on wildland fires for the needs of air quality modelling and forecasting, Atmos. Chem. Phys., 9, 6833-6847, doi:10.5194/acp-9-68332009, 2009.

Solberg, S., Hov, Ø., Søvde, A., Isaksen, I. S. A., Coddeville, P., De Backer, H., Forster, C., Orsolini, Y., and Uhse, K.: European surface ozone in the extreme summer 2003, J. Geophys. Res., 113, D07307, doi:10.1029/2007JD009098, 2008

Stavrakou, T., Müller, J.-F., De Smedt, I., Van Roozendael, M., van der Werf, G. R., Giglio, L., and Guenther, A.: Evaluating the performance of pyrogenic and biogenic emission inventories against one decade of space-based formaldehyde columns, Atmos. Chem. Phys., 9, 1037-1060, doi:10.5194/acp-9-1037-2009, 2009.

Stiller, G. P.: with contributions from v. Clarmann, T., Dudhia, A., Echle, G., Funke, B., Glatthor, N., Hase, F., Höpfner, M., Kellmann, S., Kemnitzer, H., Kuntz, M., Linden, A., Linder, M., Stiller, G. P., and Zorn, S.: The Karlsruhe Optimized and Precise Radiative Transfer Algorithm (KOPRA), vol. FZKA 6487 of Wissenschaftliche Berichte, Forschungszentrum Karlsruhe, Germany, 2000.

Stolbovoi, V. and Savin, I.: Maps of soil characteristics. In Stolbovoi V. and I. McCallum, eds. Land resources of Russia. Laxenburg, Austria: International Institute for Applied Systems Analysis and the Russian Academy of Science. CD-ROM. Distributed by the National Snow and Ice Data Center/World Data Center for Glaciology, Boulder, 2002.

Turquety, S., Hurtmans, D., Hadji-Lazaro, J., Coheur, P.-F., Clerbaux, C., Josset, D., and Tsamalis, C.: Tracking the emission and transport of pollution from wildfires using the IASI CO retrievals: analysis of the summer 2007 Greek fires, Atmos. Chem. Phys., 9, 4897-4913, doi:10.5194/acp-9-4897-2009, 2009.

van Donkelaar, A., Martin, R. V., Levy, R. C., da Silva, A. M., Krzyzanowski, M., Chubarova, N. E., Semutnikova E., and Cohen, A. J., Satellite-based estimates of ground-level fine particulate matter during extreme events: A case study of the Moscow fires in 2010, Atmos. Environ., 45, 6225-6232, doi:10.1016/j.atmosenv.2011.07.068, 2011.

Val Martín, M., Honrath, R. E., Owen, R. C., Pfister, G., Fialho, P., and Barata F.: Significant enhancements of nitrogen oxides, black carbon, and ozone in the North Atlantic lower free troposphere resulting from North American boreal wildfires, J. Geo- 
phys. Res., 111, D23S60, doi:10.1029/2006JD007530, 2006.

Val Martin, M., Logan, J. A., Kahn, R. A., Leung, F.-Y., Nelson, D. L., and Diner, D. J.: Smoke injection heights from fires in North America: analysis of 5 years of satellite observations, Atmos. Chem. Phys., 10, 1491-1510, doi:10.5194/acp-10-14912010, 2010.

van der Werf, G. R., Randerson, J. T., Giglio, L., Collatz, G. J., Kasibhatla, P. S., and Arellano Jr., A. F.: Interannual variability in global biomass burning emissions from 1997 to 2004, Atmos. Chem. Phys., 6, 3423-3441, doi:10.5194/acp-6-3423-2006, 2006.

van der Werf, G. R., Randerson, J. T., Giglio, L., Collatz, G. J., Mu, M., Kasibhatla, P. S., Morton, D. C., DeFries, R. S., Jin, Y., and van Leeuwen, T. T.: Global fire emissions and the contribution of deforestation, savanna, forest, agricultural, and peat fires (19972009), Atmos. Chem. Phys., 10, 11707-11735, doi:10.5194/acp10-11707-2010, 2010.

Vautard, R., Honorè̀, C., Beekmann, M., and Rouil, L.: Simulation of ozone during the August 2003 heat wave and emission control scenarios, Atmos. Environ., 39, 2957-2967, 2005.

Verma, S., Worden, J., Pierce, B., Jones, D. B. A., Al-Saadi, J., Boersma, F., Bowman, K., Eldering, A., Fisher, B., Jourdain, L., Kulawik, S., and Worden, H.: Ozone production in boreal fire smoke plumes using observations from the Tropospheric Emission Spectrometer and the Ozone Monitoring Instrument, J. Geophys. Res., D02303, doi:10.1029/2008JD010108, 2009.

Waters, J. W., Froidevaux, L., Harwood, R. S., Jarnot, R. F., Pickett, H. M., Read, W. G., Siegel, P. H., Cofield, R. E., Filipiak, M. J., Flower, D. A., Holden, J. R., Lau, G. K., Livesey, N. J., Manney, G. L., Pumphrey, H. C., Santee, M. L., Wu, D. L., Cuddy, D. T., Lay, R. R., Loo, M. S., Perun, V. S., Schwartz, M. J., Stek, P. C., Thurstans, R. P., Boyles, M. A., Chandra, K. M., Chavez, M. C., Gun-Shing Chen, Chudasama, B. V., Dodge, R., Fuller, R. A., Girard, M. A., Jiang, J. H., Yibo Jiang, Knosp, B. W., LaBelle, R.C., Lam, J. C., Lee, K. A., Miller, D., Oswald, J. E., Patel, N.C., Pukala, D. M., Quintero, O., Scaff, D. M., Van Snyder, W., Tope, M. C., Wagner, P. A., and Walch, M. J.: The Earth Observing System Microwave Limb Sounder (EOS MLS) on the Aura satellite, IEEE Trans. Geosci. Remote Sens., 44, 1075- 1092, 2006.
Wiedinmyer, C., Akagi, S. K., Yokelson, R. J., Emmons, L. K., AlSaadi, J. A., Orlando, J. J., and Soja, A. J.: The Fire INventory from NCAR (FINN): a high resolution global model to estimate the emissions from open burning, Geosci. Model Dev., 4, 625641, doi:10.5194/gmd-4-625-2011, 2011.

Williams, J. E., Weele, M., Velthoven, P. F. J., Scheele, M. P., Liousse, C., and Werf, G. R.: The Impact of Uncertainties in African Biomass Burning Emission Estimates on Modeling Global Air Quality, Long Range Transport and Tropospheric Chemical Lifetimes, Atmosphere, 3, 132-163, 2012.

Witte, J. C., Douglass, A. R., da Silva, A., Torres, O., Levy, R., and Duncan, B. N.: NASA A-Train and Terra observations of the 2010 Russian wildfires, Atmos. Chem. Phys., 11, 9287-9301, doi:10.5194/acp-11-9287-2011, 2011.

Wittrock, F.: The retrieval of oxygenated volatile organic compounds by remote sensing techniques. $\mathrm{PhD}$ thesis, University of Bremen, Germany, May 2006.

Wittrock, F., Richter, A., Oetjen, H., Burrows, J. P., Kanakidou, M., Myriokefalitakis, S., Volkamer, R., Beirle, S., Platt, U., and Wagner, T.: Simultaneous global observations of glyoxal and formaldehyde from space, Geophys. Res. Lett., 33, L16804, doi:10.1029/2006GL026310, 2006.

Wooster, M. J., Roberts, G., Perry, G. L. W., and Kaufman, Y. J.: Retrieval of biomass combustion rates and totals from fire radiative power observations: FRP derivation and calibration relationships between biomass consumption and fire radiative energy release, J. Geophys. Res., 110, D24311, doi:10.1029/2005JD006318, 2005.

Yurganov, L. N., Rakitin, V., Dzhola, A., August, T., Fokeeva, E., George, M., Gorchakov, G., Grechko, E., Hannon, S., Karpov, A., Ott, L., Semutnikova, E., Shumsky, R., and Strow, L.: Satellite- and ground-based CO total column observations over 2010 Russian fires: accuracy of top-down estimates based on thermal IR satellite data, Atmos. Chem. Phys., 11, 7925-7942, doi:10.5194/acp-11-7925-2011, 2011.

Zhang, Y.: Online-coupled meteorology and chemistry models: history, current status, and outlook, Atmos. Chem. Phys., 8, 28952932, doi:10.5194/acp-8-2895-2008, 2008. 